\title{
Function and dysfunction of monoamine interactions in children and adolescents with AD/HD
}

\section{Robert D. Oades}

In, "Neurotransmitter Interactions and Cognitive Function" pp.207-244 (Eds.) Edward D. Levin, Lawrence Butcher and Michael Decker : Birkhäuser Verlag, Switzerland

Biopsychology Research Group, University Clinic for Child and Adolescent Psychiatry, Virchowstr. 174, 45147 Essen, Germany: Email oades@uni-essen.de

This is the reformatted manuscript submitted - prior to publication in its final form at www.springerlink.com

\section{Contents:}

Introduction:

AD/HD - a clinical picture

AD/HD - neuropsychological features

Normal brain development

Normal neuropsychological development

The monoamine pathways

Monoamines - development

Monoamine interactions pertaining to normal cognition

AD/HD: (1) Indicators of Monoamine Metabolism: theory

AD/HD: (2) Indicators of Monoamine Metabolism: a dual pathway

Mesocortical Pathway

Cortical NA

Cortical 5-HT

Mesolimbic Pathway (DA)

Mesolimbic Pathway (5-HT)

The status of peripheral and central nervous monoamine systems

NA Metabolism

DA Metabolism

5-HT Metabolism

Conclusions:

References

\begin{tabular}{|c|c|c|}
\hline Here & & In book \\
\hline pp. & 2 & 207 \\
\hline pp. & 2 & 208 \\
\hline pp. & $3-4$ & 208-209 \\
\hline pp. & 4 & $209-210$ \\
\hline pp. & $4-6$ & $210-211$ \\
\hline pp. & $6-7$ & $211-213$ \\
\hline pp. & $7-9$ & $213-214$ \\
\hline pp. & $9-10$ & $215-216$ \\
\hline pp. & 10 & 216 \\
\hline pp. & 10 & 216 \\
\hline pp. & $10-12$ & $216-218$ \\
\hline pp. & $12-13$ & 218-219 \\
\hline pp. & $13-16$ & $220-223$ \\
\hline pp. & 16-19 & $223-226$ \\
\hline pp. & $19-21$ & $226-228$ \\
\hline pp. & 21 & 228 \\
\hline pp. & 21 & 228 \\
\hline pp. & 21 & 228 \\
\hline pp. & $21-22$ & 229 \\
\hline pp. & 22 & 229 \\
\hline pp. & 22 & 229 \\
\hline
\end{tabular}




\section{Introduction:}

A consideration of how unusual function of the monoaminergic transmitters can contribute to the clinical picture of childhood attention-deficit/hyperactivity disorder (AD/HD) involves an understanding of 3 concepts: What are the main features of $A D / H D$, how does normal brain anatomy and function develop, and how do the monoaminergic pathways interact. With this context one is equipped to look at the evidence for unusual monoamine activity and interactions in contributing to the problems found in children with AD/HD.

This chapter proposes a way to integrate the features that these concepts have in common. The first part is concerned with a description of how childhood AD/HD appears in the clinic, at home or at school. This picture then acquires structure with specific features defined by laboratory testing. To understand what might be "disordered" supposes knowledge of the organization in normal brain structure and in particular, how the organization of stimulus and response develops in the child and the adolescent. Important here is that much of the functional order is orchestrated by the monoamines. The third part sketches out where and how the long axon monoaminergic pathways reach out across brain structures and exert (normally) an adaptive modulation of function under changing circumstances. Further details are provided in other chapters.

I shall emphasize childhood AD/HD with modest reference to its manifestation in adults: I shall concentrate on the main three monoamines (dopamine, DA; noradrenaline, NA and serotonin, 5-HT) with but minor reference to adrenaline. Nonetheless this material has implications for the origin and course of $A D / H D$ outside the early developmental period. Further, it will become apparent that the full consequences of changed monoamine activity can only be fully appraised within the context of the interactions with other amine- (e.g., acetylcholine) and amino-acid transmitters (e.g., GABA and Glutamate).

\section{AD/HD - a clinical picture}

The diagnosis of $A D / H D$ usually concerns young people between the ages of 7 and 18 years. The manual of the American Psychiatric Association [APA: DSM-IV (1)] needs the presence of $6 / 9$ features for the inattentive type, a separate $6 / 9$ features for the type with hyperactivity and impulsivity, or both for the more usual combined type. The decision is based on longer structured or semi-structured interviews that ask 60-80 questions (or more) from two informants (usually a parent and a teacher) in order to show that the reported problems can occur independently of the situation. These features, impairing the function of the child, must have been present before the $7^{\text {th }}$ birthday.

The health professional will get an image of motor restlessness (chair rotation, alternately sit or stand, move from toy to toy/task-to-task, fidgeting). Fine motor control can appear clumsy. Movement is often led by impulsivity. From observation alone it is often difficult to distinguish impulsiveness driven by a distracter, changing desires/motivations or an inability to withhold prepotent tendencies. Concentration is difficult unless the situation is novel. Social abilities are poorly developed (e.g., few friends, interruption of discourse), self-esteem is often low and the ability to organize or plan deficient. The latter can incur poor judgment and risktaking. Changes in the quality of motivational features (e.g., the need to drink, assess reinforcement), stress- and emotional 
control (e.g. temper tantrums) often complete the clinical picture [review (2)].

\section{$A D / H D$ - neuropsychological features}

It must be emphasized that there is no function - typical of normal child development - that is completely absent in those with $A D / H D$. Lesions are not implicated. The patient is sometimes 'normal': but the problems persist in different contexts. A child appearing for an MR- or electrophysiological investigation can appear remarkably 'cool', for the time being. There have been innumerable disagreements over what constitutes a classical or 'core' phenotype. Of course, a way out is to define sub-groups by one or by another feature (e.g., referrals vs. nonreferrals (3), inattentive vs. hyperactivecombined subtypes (4), with/without different comorbid disorders (5), internalisers [fearful anxious types]/ externalisers [fearless impulsive types, (6)], more or fewer than 7-repeats on the dopamine D4 receptor gene (7), those with high theta/low beta EEG ratios vs. those with high beta EEG power (8), medication responders/non-responders $(9,10)$ and more. It is ironic that the feature with the most widespread applicability appears to be that of intra-individual variability (11) where it is the variance of response time that is usually considered.

Yet it is possible that the difficulties of $A D / H D$ children can be both differentiated and reduced to a few conventional fields of ability. Thus, variance in the speed of performance relates to motor abilities in general, - in the sense of neuromuscular development (12), but also to poorly controlled supplemental motor activity and physiological state control (13). Similarly the variance in accuracy can be explained by inattentiveness (12), in the sense that distracters can delay (14), focused attention /non-target detection is slow (15), and indeed signal-detection indices of perceptual sensitivity (e.g., d-prime) are low $(16,17)$. The errors that so often result do not incur the usual slowing of the next response, - implying the impaired processing of feedback and contingent executive control $(18,19)$. There are two major processes here, - the top-down control of information processing, and the short-term sensitivity to reinforcement. If these are abnormal, one consequence is that children with $A D / H D$ often express an aversion to delays in event-rates. In other words there are two separate features [dual pathway, (20)]: executive dysfunction and delay aversion make significant, independent contributions to predictions of $A D / H D$ symptoms.

A number, if not all, of these features of $A D / H D$ could be summarised under the rubric of a "disorder of impulsivity"(7). There is some truth in this. The term 'impulsivity' has 3 components, - acting on the spur of the moment (motor), not focusing on the task in hand (attentional), and not planning ahead [executive: (21)] that can all lead to ill-considered action. But it would be wise when attributing unusual neurochemistry to non-adaptive function to separate the control systems for cognitive and behavioural impulsivity (22). The alternative to lumping is to split the disorder into numerous sub-types. This will always have some explanatory value for specific features, but it is worth considering, for example, the experience of Nigg and colleagues (23). They examined executive function, motor abilities and flexibility of cognitive set, and found that the similarities between diagnostically inattentive and combined subgroups were much more striking than the differences [cf. also (24)].

Unusual brain functions in children with 
AD/HD are associated with inattention (perception and selection), poor controlled(executive)-decision processing (conflict management), non-adaptive evaluation of reinforcement contingencies and situationally inappropriate motor activity. These impairments are reflected in each of the successive stages of information processing that are so clearly and precisely represented by scalp electrophysiological records (eventrelated potentials, ERPs) in the first half second after an event: Stimulus-elicited cortical excitation [N1 reduced, (25)], interference control [P2 larger, (26)], stimulus categorization [N2 reduced, (27)], effortful updating of short-term memories (P3 reduced, (28)], assessment of stimulus 'targetness' [processing negativity reduced, (29)], assessment of mistakes [error-related negativity/Ne/Pe reduced, (30)], and motor organization (LRP reduced, (31)].

\section{Normal brain development}

With an interest in $A D / H D$ in mind, interest in normal anatomical and cognitive development centres on the classical peripubertal age for referral (8-14y) with curiosity extending to earlier features (potentially relating to causality) or how matters progress or disappear in young adults.

Myelination, white matter development, begins in the second trimester, develops linearly from 4 years \& continues through (and beyond) the third decade. In the meanwhile frontal lobe gray-matter develops slowly and gradually to 8 years of age when prefrontal development (rostral to the precentral sulcus) takes off and develops rapidly until about $14 \mathrm{y}$. Having peaked prior to adolescence, the grey matter volume then declines (32). This process is attributed to the pruning of connections (33), and may start as early as 7 to 10 years of age in sensory and in frontal association cortices, respectively. The thickness of the cortex decreases across the whole period from 8-20y (34). The peripubertal age also sees the rise of hemispheric differences (e.g. around the inferior frontal sulcus: cf. language development on the left). Some of these differences are gender specific (35).

Brain, especially white-matter-volumes, increase continually over 3 decades: overall increases of volume are found in many parts of the frontal, parietal and mid temporal (limbic) lobes, while more definite decreases occur in the lateral cortices, basal ganglia and thalamic nuclei (36-38). These studies have shown that maturation progresses in waves, rostrally in the frontal and laterally in the temporal lobes. Interestingly these separate developmental axes are reflected in a functional study showing the 'migration' along these axes of the sources of activity underlying the detection, registration and response to changes of auditory stimulation (39). Such maturational processes continue into the frontal and temporal poles throughout the third decade. Indeed, frontal grey/white matter ratios continue to decrease (linearly) even beyond that age (40).

\section{Normal neuropsychological development}

Linear increases in the rate of development of postural and sensorimotor coordination peak around 6 and 10 years of age, respectively. Continued development, particularly of the latter, depends increasingly on experience and its consequences, - described as 'enhanced programming resources' and online feedback processing $(41,42)$. Tapping in to such problems may reflect the core problems of $A D / H D$ children in cognition, on which this chapter concentrates. Thus, it should be borne in mind that motor coordination does not become mature until 
relatively late (in the second decade), alongside attentional and executive functions (38). In contrast sensory functions, orientation and speech-related abilities develop earlier in the first decade.

In late childhood (around $7 y \pm 1 y$ ) children make a qualitative leap in their cognitive abilities, allowing measures to be made of tests that have a qualitative if not a quantitative similarity to those used in the neuropsychological testing of adolescents and adults. In particular they are able to orient between cues and master conflicting stimuli about as well as older children (43). However the speed and accuracy of switching attention continues to improve with age.

As would be expected from anatomical developments briefly described above, the transition of puberty (around $12 \pm 1 \mathrm{y}$ ) coincides with the maturation of many abilities associated with the function of the frontal, or especially the prefrontal lobes. These include abstract reasoning, use of goals in making plans, inhibitory control, verbal fluency, verbal delayed recall, novelty-seeking, even finding a degree of independence from the family $(35,44)$.

But fine grain analyses of development have been rare. A series of studies by Luna and colleagues (45) on speeds of processing, the ability to inhibit voluntary responses and working memory use were all based on variations of an oculomotor task, thereby controlling for the comparison of qualitatively different task requirements. They reported that adult levels of response inhibition were not achieved before the age of $14 y^{1}$, independent of speeds of

\footnotetext{
${ }^{1}$ The emphasis is on adult levels of performance. In the preceding peri-pubertal phase children can execute such tasks (e.g. Go/no-go) but they recruit much larger areas in the frontal lobes (46) and the amplitudes of the ERPs show that their categorization
}

processing that matured a year later. Working memory performance, which depended modestly on the other two variables considered, did not attain adult levels until 19 years of age.

The development of the stages of information processing is illustrated in an exemplary way with ERP measures. The arrival of sensory information in the thalamus and sensory cortices is marked by the P1/P50. Maturation to adult levels involves a decrease of amplitude and latency by about a third between 5 and 15 years (48). The gating of the ERP response to a second stimulus (as marked by P50 in a paired click paradigm) is extremely variable at puberty (49), and may not achieve adult expression until the end of the teens (50). The development of excitation elicited by a salient stimulus (N1), along with the suppression of processing of other stimuli (P2) - as a preliminary to its being further processed - has been described for subjects aged from 5 to 30 y $(51,52)$. The N1/P2 adult waveform only becomes evident at $13-14 y$ of age. The decreases of the latency and amplitude characteristics of the peak and the dipoles do not mature until after 16 years. Around puberty the topographic distribution of the P50 peaks across the scalp move posterior and N1 peaks lose their rightward asymmetry However, P2 peaks do not move rostrally to their central adult locations until the end of adolescence. The categorization of stimuli (marked by N2) and context-updating (marked by P3) attain their bilateral frontal and parietal topography by around 17 years of age. The amplitudes of these components show a linear and curvilinear development with age, respectively, and mature around 15 years of age with latency attaining adult

of stimuli and evaluation of errors made on these and conflict tasks are in general remarkably small (47). 
levels some 3 years later $(53,54)$. Indicators of automatic selective processes (Mismatch negativity, MMN) develop about 3 years earlier than controlled attention-related processes (Negative-difference, Nd). While MMN topography becomes bilaterally distributed after puberty, the latency reaches adult levels around 17 years, but the dipoles continue to migrate along with normal frontal and temporal lobe expansion through the third decade $(39,51)$.

\section{The monoamine pathways}

As their names suggest there are three major dopaminergic (DA) innervation systems in the forebrain, with their mesencephalic origins in the ventral tegmental area (VTA) and substantia nigra (SN) in the brainstem - the mesocortical, mesolimbic and nigro-striatal projections (55). The density of mesocortical DA pathways in primates increases rostrally across the cortices. For example, the increase in the rostral auditory association cortices is already markedly higher than in the more caudal temporal lobe. A moderate then higher innervation is found moving from somatosensory over motor to prefrontal association areas. The axons are especially dense in layers I and II and again in V and VI (56). DA D1 receptors (dense in I-IIla, moderate in $\mathrm{V}$ and $\mathrm{VI}$ ) are present at one to two orders of magnitude more than those of the D2-family; but in this D2-family the D4 type of receptors are more evident in the neocortices (e.g. layer V), and the D2 types in the limbic and temporal regions. Important recipients of mesolimbic innervation include the entorhinal and cingulate cortices (transitional and archicortices), parts of the hippocampus and amygdala, and the ventral striatum (nucleus accumbens and septum). Oades and Halliday (55) pointed out that these regions are 'nodes of convergence' of input from very many brain regions and represent excellent opportunities for DA activity to influence the shifting of the control of their efferent output between different afferent sources (figure 1).

The main noradrenergic (NA) projections to the limbic and cortical brain regions of concern here arise in the locus coeruleus (LC) of the pontine brainstem. NA fibres project throughout the forebrain, to the phylogenetically older archicortices (hippocampus and amygdala), the neocortical mantle, but also the cerebellum. This more dorsal pathway along with a more ventral one from the nucleus tractus solitarius also innervate several subcortical regions including the thalamus and hypothalamus (57). Innervation in the neocortices increases from layers I-V with highest densities in II and IV with greater densities of the alpha and beta receptors in the more superficial layers (56). Alpha-2a sites, prominent in frontal regions, may be pre- or post-synaptic in location, while alpha-1 sites more often exert effects presynaptically: the former inhibiting, and the latter enhancing monoamine release (58).

Relevant to forebrain function, 5-HT projections originate in the median and dorsal raphe on the border of the pons (containing the $\mathrm{LC}$ ) and midbrain (containing the VTA). There is some overlap between the areas innervated, but the dorsal raphe projects more anteriorly, to the frontal cortices and basal ganglia, and the median raphe somewhat more to limbic structures and the diencephalon. The sensory and motor cortices display a decidedly patchy distribution of low and high levels of innervation (59). Much of the input arrives in layers III and IV (60). Two of the most studied 5-HT binding sites in the CNS are the 


\section{Regions of Convergence}

\section{Prefrontal Cortex}

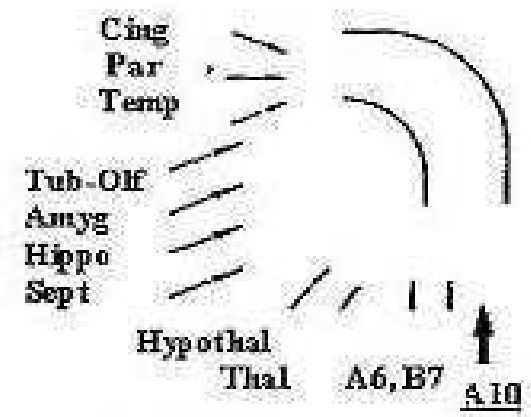

Septom

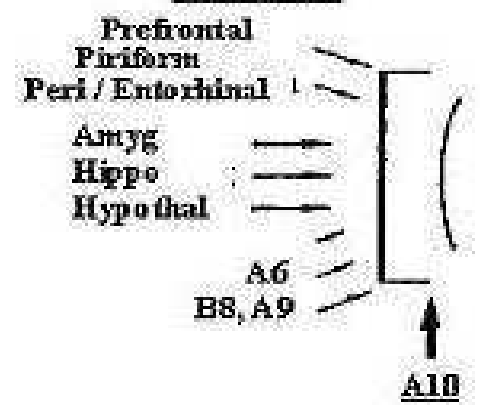

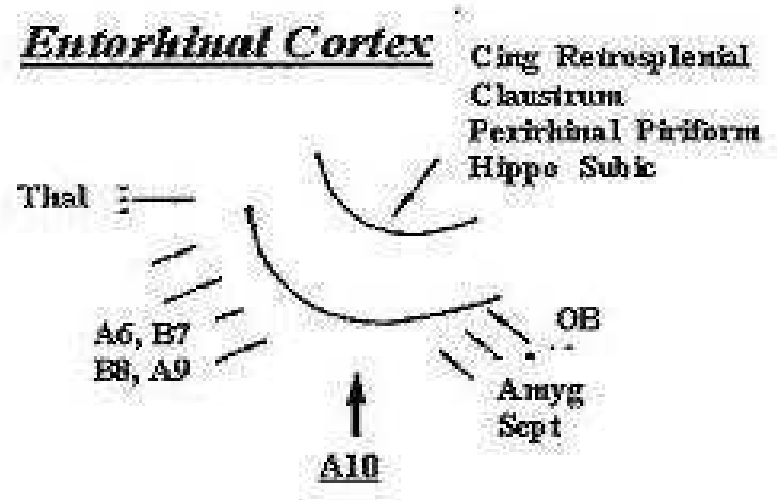

Nuclens Accumbens

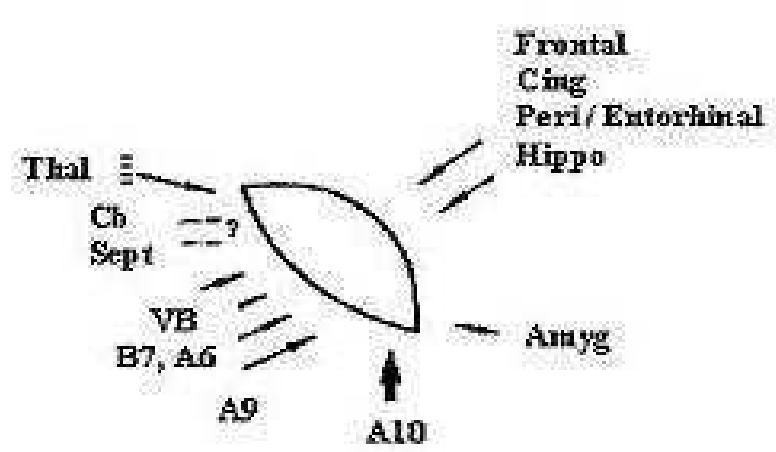

\section{Figure 1}

Nodes for the convergence of afferent fibre input on two mesocortical and two mesolimbic DA projection regions (prefrontal and entorhinal cortices, the nucleus accumbens and septum). Reproduced from (55) with permission from Elsevier.

Amygdala (Amyg), Cerebellum (Cb), Cingulate cortex (Cing), Claustrum, Entorhinal cortex, Frontal cortex, Hippocampus (Hippo), Hypothalamus (Hypothal), Infero-temporal cortex (Temp), Olfactory bulbs (OB), Parietal cortex (Par), Prefrontal Perirhinal, Piriform and Retrosplenial cortex, Septum (Sept), Thalamic nuclei (Thal), Tuberculum-olfactorium (Tub-Olf), Ventral noradrenergic bundle (VB): Monoaminergic nuclei (A/B 6-10).

5-HT1a and 5-HT2a receptors. The former is often characterised as an autoreceptor, and the latter postsynaptic, but this is not an exclusive compartmentalization (e.g. 5-HT1a sites are active postsynaptically on cholinergic neurons). Stimulation of either site can lead to increased catecholamine outflow $^{2}$ (61-64).

\footnotetext{
${ }^{2}$ This generalization glosses over the variation with brain region, receptor sub-type (e.g. 5-HT2c, 5-
}

\section{Monoamines - development}

DA neurons enter the cortical plate early in the second trimester. DA has a trophic role at this early stage, whereby impairments can have consequences on the later thickness and connectivity of the cortex (65). From birth to puberty the

HT1b), the mechanism (through an effect on release or synthesis) and whether the catecholamine neuron is in a tonic- or burst-firing state. 
number of axons can increase 6-fold before pruning processes set in. Numbers of DA receptors peak in mid-childhood, already decreasing well before puberty [D1 earlier than D2: $(66,56)]$. Across adolescence to adulthood the number of D1 sites falls by nearly $50 \%$ and D2 sites by nearly $60 \%$ (67): thereafter numbers of D1 sites decrease by a few percent per year. The implication that the $D 1 / D 2$ ratio falls with age is notable. In studies of rodents the peak for D2 receptors seems to be larger in males, and despite the ensuing reductions, levels are still higher than in females through adolescence (68). (The same study also described more D1 sites in right than left sided subcortical regions that lasted from the post-pubertal period into adulthood: this is reflected by measures of DA and its metabolite DOPAC that showed a lower turnover in the left hemisphere until inter-hemispheric coupling matured in young adulthood (69). Such findings are yet to be confirmed for humans.) The DA transporter system follows a different course, peaking at puberty and gradually decreasing right on through to 50 or 60y of age [postmortem study: (66)]. This matches the inverse changes for the synthesis of DA (by tyrosine hydroxylase) that in non-human primates continues to develop right through into adulthood (70). The gradual decrease of transport mechanisms may accurately reflect functional activity, and are directly reflected by the gradual decrease of DA turnover seen in urinary measures taken between 10 and 20 years of age (71).

NA development in the human foetus follows but at first lags a little behind that for DA in the perinatal period $(72,73)$; but if data from animal studies pertain then it soon speeds up and overtakes that for DA (74). In studies of primates and other animals alpha- 2 and alpha- 1 types of receptor also follow each other in developmental waves, with the alpha-2 ahead at birth. But levels fall off after birth as numbers of alpha 1 sites increase. Yet by puberty alpha-1 sites are decreasing more rapidly than the alpha-2 sites. Transport mechanisms are gradually reduced following puberty but increase again by the end of adolescence [review (59)]. This postpubertal decrease followed by an increase across the teenage period is reflected in urinary indicators of NA turnover (71).

5-HT development reflects first a prenatal neurotrophic role, and second a postnatal expansion of neural innervation and function. A study of Rhesus monkeys from 2 weeks to 10 years of age (70) showed that while the development of catecholamine-containing appositions on cortical pyramidal cells reached half adult levels by 6 months of age - 5-HT appositions had already attained adult levels by 2 weeks. Prepubertal development, though considerable, appears paradoxically to be functionally slower than that for DA, such that CSF measures suggest a near doubling of the ratio of DA to 5-HT metabolites over the prepubertal period [review: (59)]. Postmortem tissue (75) and urinary measures (71) suggest that rather like the situation with NA, 5-HT turnover decreases initially post-pubertally, but then rises again at the end of the second decade. If studies of rodent development are any guide considerable lateralised differences are to be expected. Neddens and colleagues (76) reported a rightward emphasis of fibre density in the neocortices and a leftward emphasis in the limbic cortices.

Clearly there remains alot of detail on the development of the various features of monoamine systems to be described: the near absence of knowledge of the relative abundance of the different receptor 
subtypes is striking and only partly explained by the fairly recent availability of suitable ligands. The results reported in this section show that there is no simple way to say that the functional activity of one or the other monoamine (let alone their interactions) is more or less than adult levels at a given age. First the baseline of adult levels is continually changing with age. Secondly it remains unfortunately equivocal whether any specific function considered is more accurately represented by turnover, synthesis rates, transport mechanisms or the development of synaptic appositions on innervated pyramidal or non-pyramidal cells. Each of these features develops at different non-linear rates.

\section{Monoamines interactions pertaining to normal cognition}

Brain-damage or insults to the monoamine systems alone do not allow unequivocal conclusions to be drawn about hypo- or hyper-function in the affected system. But they do provide some insight into the normal situation by seeing in what domains there are dysfunctions. Preclinical studies [e.g. reviews: (77-79)] suggest that damage impairing NA function increases distractibility. NA tunes the influences of the inputs competing to control the output of an NA innervated region. Low to high tonic firing rates are associated with inattention and low arousal to agitation and stressed states. In contrast phasic firing occurs when stimulation is relevant, other activity should be tuned down (80). Impaired 5-HT function is associated with impulsivity, whereby decreased function may relate to outbursts of aggression, while increases are associated with cognitive impulsiveness (8183,22 ). By analogy with the role of NA in tuning, studies of stimulus control suggest that 5-HT very often appears to influence transmission by exerting a volume-control or gain function $(59 ; 84)$. By contrast, the role of (increasing) DA activity has been described as one of facilitating the likelihood of a switch occurring between one of two inputs controlling the output of a given brain region (79). Reducing DA function thus leads to the slowed switching in of a particular cued response (85). This can be advantageous in initial learning. In contrast, high activity enhances switching as in divided attention, or between attentional and task sets [e.g. trail making, or discrimination reversal: $(86,87)]$. While low and high levels of DA and NA activity, respectively demonstrate the different roles of tuning and switching in initial learning there are other situations in the control of ongoing behaviour when their function can appear rather similar as a result of the presence of different receptor subtypes ${ }^{3}$.

There are numerous complications that make for difficulties in the interpretation of the results of the manipulation of any one of the monoamines. I shall mention a few. NA neurons have sites that will transport NA and DA, and others that can release NA or DA (89). This makes it very difficult to determine precisely the mechanism by which, say, psychostimulants achieve a specific cognitive effect. Questions are not limited to the role of DA. NA is known not only for its high affinity for the alpha-2 and low affinity for the alpha-1 binding site, but is a relatively good ligand at the DA D4 site (90). Interactions between the two

\footnotetext{
Arnsten (77) provides an example of NA involvement in switching between channels of activity. Information may be faithfully transmitted from the thalamus to the cortex under conditions of sufficient NA release to engage $\alpha 1$ and $\beta$ NA receptors. But when low levels of NA are released $\alpha 2$ receptors are engaged. Then, thalamic neurons enter a burst mode which prevents information transfer (88). In this way, the varying affinities of NA for $\alpha 2$ vs. $\alpha 1$ or $\beta$ NA receptors acts as rather like a 'switch to alter neuronal, and the ensuing behavioural state.
} 
catecholamines are also documented. For example, NA receptors have even been hypothesised to 'gate' DA release (91).

It has long been realised that $5-\mathrm{HT}$ input frequently inhibits DA activity: now a better understanding of the HT2a binding site has shown that this effect must also extend to the NA system (64). However, opposite effects on catecholamine release are attributed to HT1b, HT1d and HT3 binding sites. The fact that both alpha-NA and 5-HT1 sites may be found in pre- and post-synaptic locations warns against generalizing about a transmitter's activity being associated with one-dimensional changes of any one cognitive ability (59).

\section{AD/HD: (1) Indicators of Monoamine Metabolism - theory}

Let us take a 'top-down' approach from the viewpoint of theories currently advanced to explain AD/HD problems. There are 2-3 broad explanations that nonetheless do not account for all features and 2-3 that account for a domain of dysfunction, but extension beyond these domains remains controversial.

First there is the dual pathway theory (92) and the cognitive energetic model (93). The former directly invokes monoaminergic involvement and provides the background to the rest of this chapter. The latter is pitched at the psychological level of state regulation with physiological underpinnings, but elaborates little on the monoaminergic contribution. A related account (13) explicitly accounts for a range of $A D / H D$ problems (variability and maturation) at the level of energy availability in CNS function, but only indirectly invokes modulation by the monoamines.

Other theories aim at generalizing from specific domains of performance such as response inhibition $(94,95)$ to executive function and affect control, and the 'dynamic developmental theory' (96) that concentrates on the registration of reinforcement and related motivational consequences [see also reviews in $(5,97)$ ]. All these theories depend on functions modulated by DA (prima unter pares). They tend to overlook the role of NA and $5-\mathrm{HT}$, but do admit dependence on the interactions with excitatory and inhibitory transmitters (Glutamate, GABA and acetylcholine), without much elaboration.

Most of these theories also do not pay adequate attention to explanations that could account for rates of comorbidity, maturation lag, impulsivity, stressresponsivity and sleep-wake patterns, to name a few other abnormal features associated with the phenomenon of $A D / H D$.

\section{AD/HD: (2) Indicators of Monoamine Metabolism - a dual pathway}

This theory invokes a role for the mesocortical DA system in modulating (deficient) dorsal fronto-striatal glutamatergic mediation of some executive functions. It also envisages a role for the mesolimbic DA system in the anomalously functioning reward and motivationinfluencing circuits of the more ventral frontal-accumbens glutamatergic system (92).

\section{Mesocortical pathway}

Direct evidence for the involvement of the mesocortical pathway is rather recent. Neuroimaging evidence from subjects with $A D / H D$ suggests less activity in the right prefrontal regions and parts of the basal ganglia (the caudate nucleus and pallidum) during a continuous performance test of sustained attention [in children, (98)], but also in these areas (inferior frontal) and in the cingulate region during stop-signal and Go/no-go tests of impaired response 
inhibition and impulsivity (in adolescents, (99-101)]. Indeed, no significant increase was found in $A D / H D$ children on interference suppression [as exhibited during performance of a flanker task: (102)], where the activity recorded in normal children in the mid- and inferior frontal regions correlates with success (103). The emphasis on right inferior frontal regions is warranted by a detailed study relating the location of brain damage to stop-task performance in brain-damaged adult subjects (104). But we should also note with regard to the $\mathrm{FMRI}$ studies that blood oxygenation (BOLD) signals are low across many brain regions, - even in the cingulate gyrus during Stroop tasks when performance in the interference condition was actually unimpaired (105).

In general MR-anatomical studies of $A D / H D$ subjects give little clue as to whether any particular region, such as those just mentioned, is altered in size or development. A small reduction is recorded as widespread through the cerebral and cerebellar lobes (106). However, grey matter reduction in the right prefrontal (107) as well as in the caudate regions (108) in these studies is noteworthy.

The prefrontal and cingulate regions discussed receive a mesocortical DA innervation. But is DA involved? Relevant to this point are further studies on the ability to switch attentional set. The ability as tested by the trail-making test has been identified as potentially belonging to the core cognitive endophenotype of $A D / H D$ (23). In a task where the subject had to map words/symbols to response hand under changing conditions, switching proved especially inefficient for those with brain damage to mid- and the already described right inferior frontal region (109). Such switches have been related to DA activity
(79), and in accord with expectations methylphenidate enhances performance of $A D / H D$ children in the stop-task (110) and reduces the cost of switching between letter/number sets $(111,112)$.

As one of the striking features of prefrontal blood flow activation during cognitive challenge is that these are absent or reduced in adolescent and adult subjects with AD/HD [fMRI above, also PET studies, $(113,114)]$, it is important to note that behavioural responses and brain activity in these regions are altered by methylphenidate treatment. However, while thalamic or cerebellar activity may increase, that in the relevant frontal regions decreases (115). This must in part be a reflection of the marked increase of synaptic DA (and blockade of DA reuptake [50\% at therapeutic doses]) known to follow treatment with methylphenidate in healthy subjects (116). In turn such changes have been directly and quantitatively linked to the interest, motivation and success in subjects who completed simple maths tests (117). However, two further findings provide a clue of how, with care, these results should be interpreted. Firstly, in cocaine-addicts methylphenidate actually increases metabolism in BA11 and BA 25 (orbitofrontal cortex) regions registering salience, motivational and emotional reactivity (118). Secondly increases of PET metabolic measures were recorded after double dosing (119). In both situations increases of DA D2 binding are expected, and it is binding in the DA D2 family of receptors that correlates with metabolism across a whole range of frontal cortical regions (120). Indeed, the variability of biochemical or behavioural response depends on the individual baseline for DA D2-like binding.

So one may entertain the hypothesis that 
the $A D / H D$ deficit may be related to an unexpected low or a relatively low level of DA binding in the individual, and his or her baseline binding status. However, if an increased chance of binding is to be therapeutic, it should probably reflect the rapid on/off (high $k_{\text {off }}$ ) type (i.e. impulse related). The reasoning is first that synthetic activity marked by PET studies of DOPA decarboxylase are lower in frontal regions of adult AD/HD patients (121). [Higher levels seen in the midbrain of younger patients (122) may reflect the mesolimbic pathway (see below).] This would lead to a low availability of DA especially when there is impulse activity. Secondly, a faster clearance of DA (by catechol-o-methyl transferase, COMT) is associated with improved performance in tests of sustained attention and time estimation $(123,124)$ especially in the inattentive type of $A D / H D$ patient. Faster clearance is achieved by those with the valine variant of a functional polymorphism (Val158Met) of the COMT gene than by those with the methionine variant.

Now we should add the complication that in the frontal cortices the binding site referred to may be the DA D4 site that is the more abundant member of the D2-family present. The type of rapid binding referred to above may well be influenced by the number of transmembrane repeated elements to be found in the molecular structure of the receptor. The D4 gene with 7 (or 2) repeats may be the form showing biased transmission in Occidental and Asian samples of $\operatorname{AD} / \operatorname{HD}(125,126)$. Currently the contrast of groups with or without the 7 repeats shows relevant but rather minor cognitive problems. Those without the 7 repeats showed more variable responses, longer response times and were mildly inattentive $(7,127)$. Those with 7 repeats were without problems on a colour-word, cued detection or rapid choice reaction time task (127), yet more impulsive on a Go/nogo task (7). A third laboratory has reported that homozygotes for the 4 repeat form tended to be those with a reduced brain volume $(128,129)$. Our understanding of the mechanisms at work here is clearly in a process of evolution, but the evidence points to important variability in DA D4 function in $A D / H D$.

\section{Cortical NA}

With the, as yet, modest effects noted to be associated with several (but not all) forms of the D4 binding site, one should consider the interaction of the mesocortical DA system with other monoamines. The intimate interactions of NA with DA processes cannot be overlooked. The NA transporter (NET) can take up both NA and DA (130). Such neurones can also release both NA and DA $(89,131)$. Further NA is a high affinity ligand for the DA D4 binding site $(78,90)$. NA receptors may even control the cortical release of DA, - for with the alpha-1b site knocked out animals showed no extracellular release of DA in response to amphetamine treatment (91). The role of NA must be considered in view of the well documented therapeutic effects of the newer (atomoxetine), as well as the older uptake inhibitors (desipramine, imipramine), the alpha-2 agonists (clonidine, guanfacine), let alone the psychostimulants methylphenidate and amphetamine that affect both catecholamines similarly (132).

The role of NET in the function of the "mesocortical pathway" is prominent in the response to methylphenidate, as it is far more abundant than the DA transporter (133). Indeed some changes in the NET genotype (G1287A, NET1) have already been reported to be associated with $A D / H D$ (134) and in particular the symptoms of 
hyperactivity and impulsivity (135): [pace negative results for other polymorphisms in three studies (136-138)]. These symptoms are improved by atomoxetine treatment (139). Tantalising but as yet equivocal evidence has been reported for associations of polymorphisms of the synthetic enzyme and alpha-2 receptor sites with inattentive symptoms (140-142).

Effects of NA associated with cognition probably occur through one of the 3 forms of the alpha-2 receptor located largely postsynaptically and with a high affinity for NA. [Alpha-1 and beta sites have a lower affinity for NA and may come in to action in stress situations associated with high levels of NA (77)]. In the monkey model infusion of guanfacine into the ventrolateral PRF strengthened associative learning and impulse control $(143,144)$. In dorso-lateral regions an alpha-2 antagonist induced some behavioural hyperactivity, more errors of commission on sustained attention tasks and no-go errors on Go/no-go tasks (77, $145,146)$, reminiscent of the features of AD/HD children. These effects are consistent with what we know about the normal role of NA. The locus coeruleus, the pontine nucleus of origin of the cortical NA fibres, shows tonic slow firing rates in the waking state: the appearance of stimuli relevant to the ongoing situation elicits clear phasic increases of neuronal firing, thereby also suppressing responses to irrelevant stimuli (80). This role is consistent with a 'tuning' function for NA activity (79).

While published descriptions of neuroimaging studies relevant to the role of NA in $A D / H D$ are still awaited, there are some data from electrophysiological studies. The sort of $A D / H D$ subject that profits from imipramine treatment (that may affect NA and 5-HT systems) is one who shows EEG characteristics of a maturational lag (147): these subjects show a widespread increase of theta power - expected to decrease with development - but reduced power in the beta and alpha bands posteriorly). The theta power also tends to normalise following methylphenidate treatment, especially over right frontal regions (148). Robust clinical responders to psychostimulant medication show an anterior/posterior ratio of the P300 ERP amplitude exceeding 0.5: just over half of the subjects tested on atomoxetine also showed this characteristic (149). In a visual or auditory oddball paradigm methylphenidate treatment is associated with increaseing the small P3a and P3b characteristic of unmedicated patients $(148,150,151)$. Indeed sometimes both latency and the amplitude variability across subjects is reduced by methylphenidate treatment (152). The enhancing effect on P3 (and processing negativity) is largely seen with target processing, consistent with an NA facilitated tuning effect $(153,154)$. Probably reflecting both the NA and DA effects of methylphenidate, stimulant treatment also normalises early stages of information processing (a reduction of the large N1 and P2 amplitude, and increases of the size of the N2 in Go/no-go tasks: $(155,156)$.

\section{Cortical 5-HT}

It is not widely appreciated that changes in the 5-HT system may contribute to the clinical picture in AD/HD. This view arises out of the lack of an effect of the major pharmacotherapeutic agents on 5-HT activity $^{4}$. Hence there have been few studies of direct relevance to this chapter. Genetic,

\footnotetext{
${ }^{4}$ It is also not widely appreciated that atomoxetine binds to the 5-HT transporter with an affinity, very approximately, only an order of magnitude less than for the NET. For comparison it binds to DAT with an affinity three orders of magnitude less, and methylphenidate has an affinity for the 5-HT transporter well over 4 orders of magnitude less (157).
} 
biochemical and neuropsychological evidence has recently been reviewed (59).

One must first bear in mind that in brain regions where there is a common innervation from DA and 5-HT fibres, 5-HT activity modulates that of DA. Receptors are found on mesocortical DA fibres where HT2c sites modulate tonic DA outflow, while HT2a sites affect active DA transmission (61, $158)^{5}$. Thus it is not surprising that CSF measures of the metabolites of both monoamines are often inter-correlated, and were reported to decrease in $A D / H D$ subjects responding to methylphenidate treatment (162).

From a functional point of view shifts of attention facilitated by methylphenidate are impaired by reducing 5-HT synthesis in healthy young adult subjects (163). Let us take the example of the cognitive challenge of conditioned blocking. Healthy children switch out the influence of superfluously related stimuli while learning a conditioned association (164). This is associated positively with levels of DA metabolites (HVA) excreted, but negatively in AD/HD children experiencing difficulties with conditioned blocking. Additionally the AD/HD children showed a positive association with the removal of 5-HT metabolites (5-HIAA). This is consistent with the $A D / H D$ children removing high levels of 5-HIAA and showing low HVA/5-HIAA ratios of relative metabolic activity. This result contributed to the authors' suggestion that with respect to 5-HT activity AD/HD children show hypodopaminergic activity (165). This is also consistent with the authors' report of correlations between cognitive impulsivity measured on the stop-task and decreasing affinity of the 5-HT transporter, that would

\footnotetext{
5 The HT2a effects are better documented from the mesocortical projection, and the HT2c effect on tonic DA outflow from mesolimbic projections (159-161)
}

lead to higher levels of 5-HT in the synapse and correspondingly more metabolism (22). Rubia and colleagues (166) also report fMRI evidence from young adults of cognitive control by the $5-\mathrm{HT}$ system. Decreased 5-HT synthesis induced by an amino acid drink related to more left-right hand choice errors on a Go/no-go task using arrow-cues. The change in 5-HT levels was associated with decreased BOLD signal from the inferior and orbital frontal cortices, but an increased signal in the temporal lobe. (The former regions were noted above to be of special interest in explaining function in $A D / H D$.)

In continuous performance tests, perceptual sensitivity (d-prime) falls with an increased excretion of 5-HT metabolites (16). The relationship of DA to 5-HT activity (HVA/5-HIAA) is depressed in some samples of $A D / H D$ children (165), although increases of this ratio may reflect motor activity (167). Let us consider some direct measures of the role of $5-\mathrm{HT}$ in the processing of salient stimuli in the sensory and association cortices.

The amplitude of the N1 to P2 ERP elicited by auditory stimuli can depend on their loudness. These two components reflect the excitatory response to salient stimuli and the allocation of resources for further processing. The augmenting response reflects $5-\mathrm{HT}$ neurotransmission and has been used to predict clinical responses to 5-HT agonists in affect disorders (168). The slope is decreased following 5-HT uptake inhibition (169). Although the activity of other transmitters (e.g. DA and acetylcholine) can also influence responsiveness $(169,170)$, the $P 2$ component can be viewed as a marker of the role of $5-\mathrm{HT}$ in the interplay with the catecholamines in the auditory cortices (171). Long ago it was noticed that the response of autistic children to fenfluramine 


\section{Event-related potentials (ERP) putatively influenced by 5-HT activity} increased P2 amplitudes in ADHD

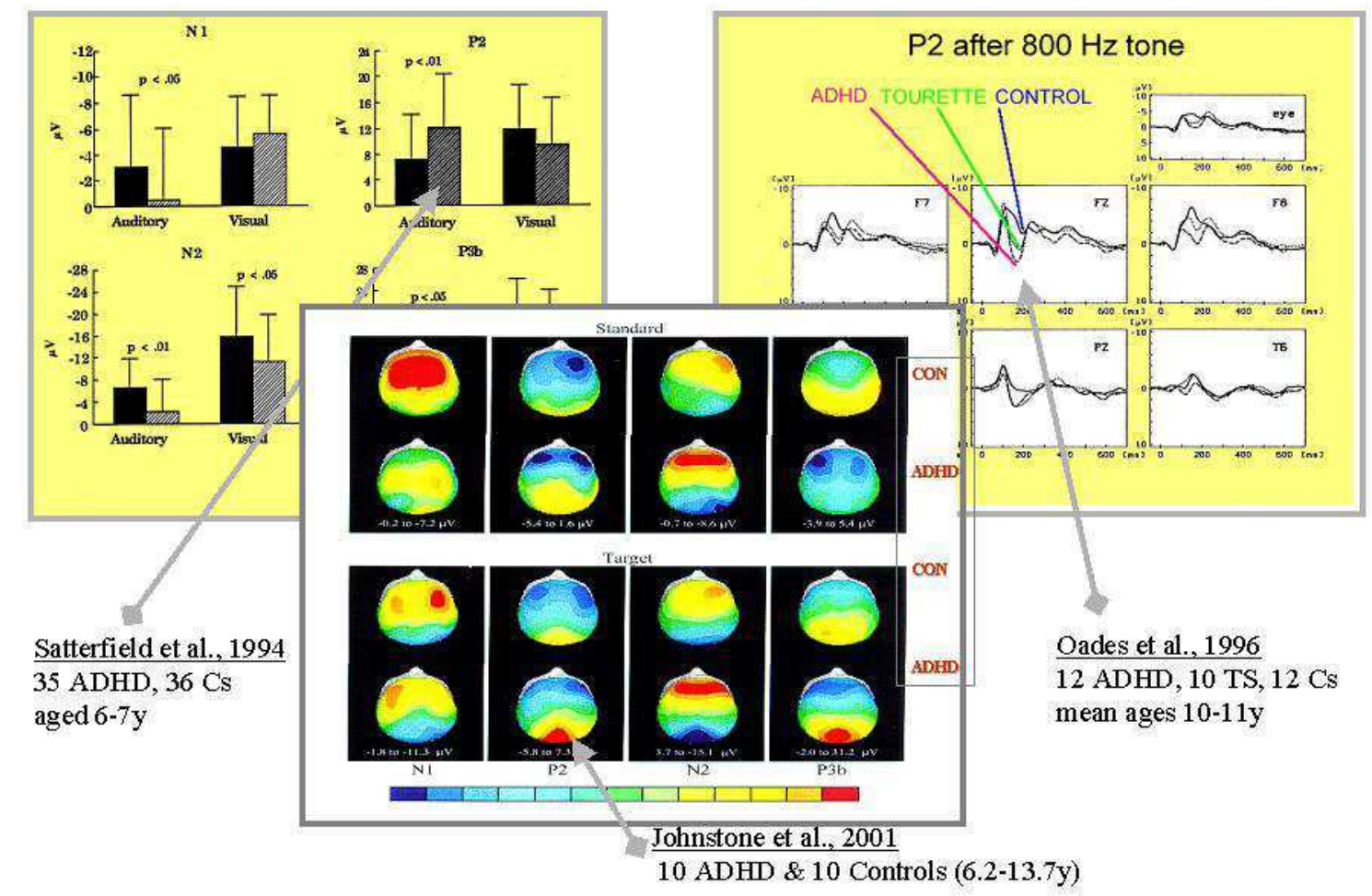

Figure 2

Three ERP studies of AD/HD children showing a P2 component of large amplitude that may reflect anomalous serotonergic activity. [The figures are modified after $(26,249,250)$ and reproduced with the permission of Elsevier, Blackwells and the author, respectively.]

and $A D / H D$ children to methylphenidate could be predicted by the augmenting response (172, 173). More recently, numerous studies describe the frequent occurrence of unusually large P2 amplitudes in $A D / H D$ children - three are illustrated in figure 2. The 5-HT influence may be more widespread. 5-HT suppression through amino acid drinks increases mismatch negativity (that marks the detection of deviant stimulation) - so increased activity may impair. The impairment of right frontal $M M N$ in $A D / H D$ children may reflect this (26). The MMN sources known to include the right inferior frontal region are also those noted in fMRI studies (discussed above) to be sensitive to $A D / H D$ impulsivity and 5-HT activity $(99,166)$. One of the other sources of mismatch negativity is located in the cingulate cortex (174), alongside dipoles for the event-related responses recorded after error commission. One of these components (the $\mathrm{Pe}$ ) may be reduced in AD/HD children (19). Responses to error commission are sensitive to the activity of the 5-HT transporter. Variations in the transcriptional control region of the gene (5HTTLPR) come in short and long versions. The low activity short variant is associated with larger error responses in healthy subjects (175) - so that one would predict that the long variant may be associated with 
reduced Pe. Indeed biased transmission of the long allele has been reported recently for AD/HD (176). Associations of the one or the other form with the 7-repeat DA D4 allele have been related to opposite extremes of temperament and anxiety in infants (177), and together with those for 5HT may represent significant markers for AD/HD (178). Lastly, supporting the thesis of over-activity in the 5-HT system, reductions of the 5-HT metabolite have been noted for hyperactive children responding to medication (179).

Against this background, it may be borne in mind that there are several mechanisms that could mediate the 5-HT/DA interactions in $A D / H D$. Thus, the nature of the $5-H T$ transporter (5-HTTLPR) will affect the expression of 5-HT binding sites: for example the short allele is associated with a lower binding potential of the HT1a site (180). Agonism here is associated with reducing $5-\mathrm{HT}$ activity that inhibits DA release in terminal regions (181). This could be one mechanism to combat hyperserotonemia. In contrast, agonism at DA D2 sites has been shown in microdialysis investigations directed at the dorsal raphe origin of 5-HT projections to increase 5-HT release $(182,183)$. This would suggest caution in the exploration of useful DA agonists. With regard to ongoing treatment with methylphenidate, 5-HT agonism (quipazine) in animals can interact to enhance the down regulation of the DA transporter (184). On the presynaptic bouton stimulation of both the D2 autoreceptor and the DA uptake site can change the sequestering by the vesicular monoamine transporter (VMAT-2) of transmitter be it DA or 5-HT (185, 186)(figure 3).

\section{Mesolimbic Pathway (DA)}

Leading animal models agree that the DA transporter (DAT) appears both to work inefficiently and be over-expressed in the mesocortical pathway. By contrast, these models disagree on the nature of the different situation in the mesolimbic system (187). Mesocortical function is dominated by the NET control of both DA and NA clearance and release, exacerbated by disorder in the relatively sparsely distributed DAT control. NET is barely present in most of the regions modulated by the mesolimbic projections, but DAT is prominently represented.

The major targets of the mesolimbic DA pathway ascending from the mesencephalic VTA are the nucleus accumbens, amygdala and the hippocampal complex (55). These regions receive topographically distributed glutamatergic input from dorsal and orbital frontal cortices, and provide feedback via GABAergic and glutamatergic pathways over several thalamic nuclei. Unusual activity in these constituent circuits modulated by the mesolimbic afferents are postulated to account for the aversion of many AD/HD children to delays. They can wait, but usually prefer a small reinforcement over waiting for a larger one [reward discounting: (92)]. Support for this being a prominent determinant of $A D / H D$ behaviour comes from many studies (188-191). This characteristic is interpreted as an inefficient coupling between current responses and future rewards. The result is a reduced control by future salient events on current events - the gradient between the two is short and steep (96).

The difficulty lies not in arguing whether there are problems in processing delays and discounting rewards in children with AD/HD, but in refining our understanding what are the components of this phenomenon. For example, animals with lesions of the amygdala also prefer immediate over later, 


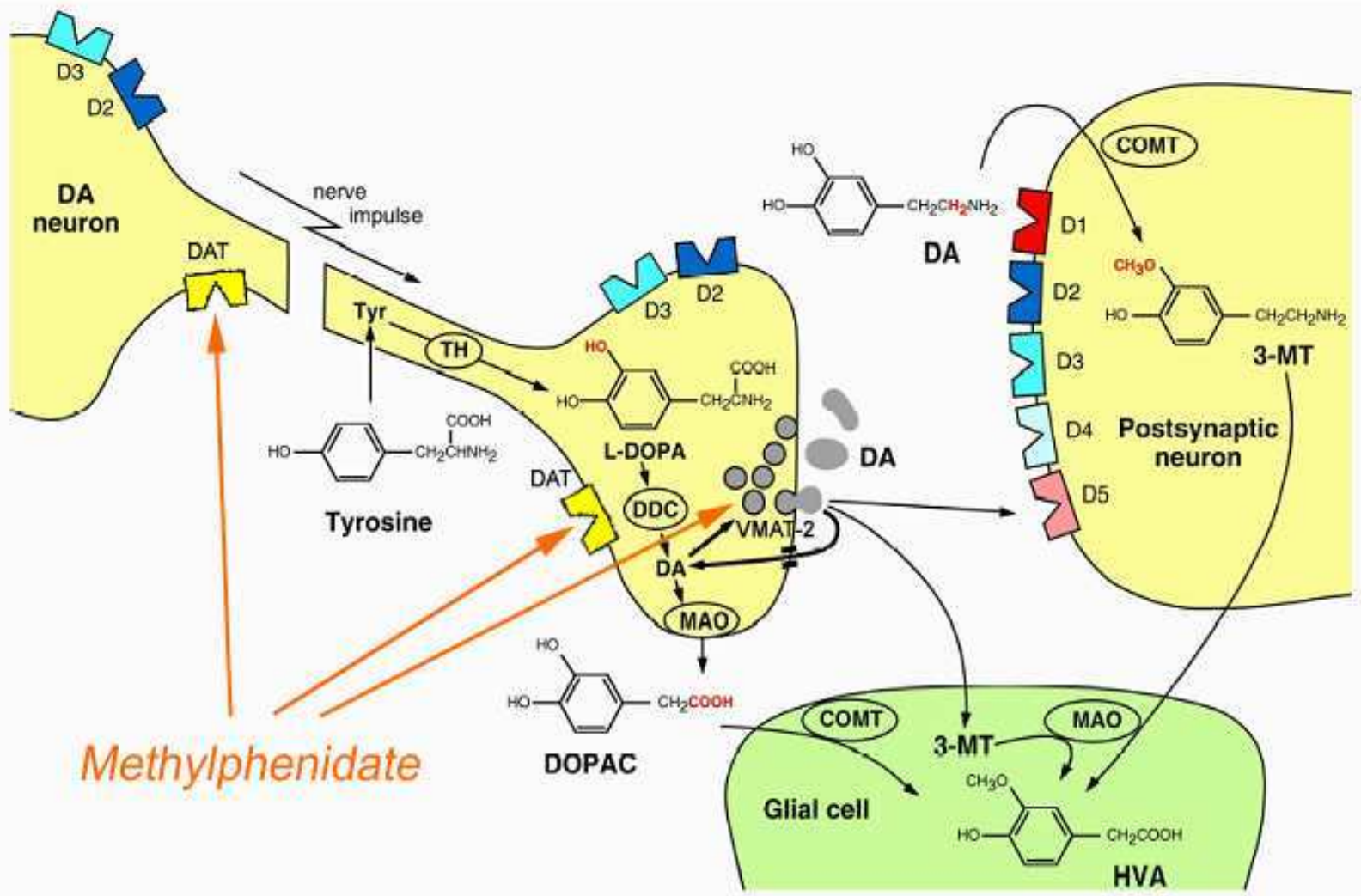

\section{Figure 3}

A scheme illustrating the synapse of a dopaminergic neuron, with the presynaptic bouton on the left at the end of an axon leading from the cell body, and the post-synaptic element on the right. The 5 types of DA receptor that may occur post-synaptically are illustrated although they would not all be found in the same synapse. The contribution from an astrocyte is symbolised by the glial cell below. The synthetic pathway for DA is illustrated pre-synaptically. The points for the potential action of medication (methylphenidate) are illustrated as a) the DA transporter on the cell body and on the bouton, and b) the vesicle monoamine transporter (VMAT-2) where newly synthesised DA is taken up prior to exocytosis in the cleft: [modified after (96) and reproduced with the permission of Cambridge University Press]

larger rewards. However damage to the input from the orbital frontal cortex has the reverse effect (192). This could be described as a system that controls 'impulsivity' (193). Do meso-accumbens DA pathways mediate incentive motivation and reward (194) or do they (more parsimoniously) enhance a switch between circuits influencing the processing of more or less salient information (195) It should not be overlooked that communication about reward (via some DA pathways) has much to do with its mediation by the orexin / hypocretin output from the lateral hypothalamus and amygdala (196).

At the behavioural level there is an apparent choice of $A D / H D$ children to respond to immediate events over other possibilities. How does DA availability affect this? The answer here requires an understanding of what may be happening at the synapse of an AD/HD patient with/ without medication (figure 3). Normally in the basal ganglia (in contrast to 
mesocortical regions) the ratios of DA, DAT and receptor densities are similar and the function of DAT is likely to be a major contributor to DA signalling (133). Efficient DAT limits the duration of DA induced synaptic activity - at low DA levels it stimulates DA release, at higher levels the DA D2 autoreceptor attenuates release (133). One would presume that psychostimulants are efficacious, as the first of these two processes is impaired. But this need not mean that the DA system is hypoactive. The increase could activate the D2 autoreceptors to reduce the (over)release of DA especially that associated with the neural impulse. Indeed methylphenidate also reduces the rate of spontaneous firing in mesolimbic neurons (197). Thus the overall effect of treatment could be to increase tonic, but to decrease phasic DA release (198). This would seem to fit the data from Schultz's monkeys (194). He related a fast phasic component of the neural response to reward prediction: this may be too strong in AD/HD and should be attenuated to allow delayed behavioural response. Grace (198) suggested that through delayed development the reduced cortical glutamatergic input to the accumbens would lead to a hypoactive DA system. This proposal has been incorporated in the dynamic developmental model of Sagvolden (96).

In adult subjects with AD/HD striatal DAT binding was reported to be unusually high (a SPECT study), and was reduced by nearly $30 \%$ after a month of methylphenidate treatment (199). This supports the notion (above) that tonic levels of DA would increase, as confirmed for normal adults (200). Interestingly, in animals, coadministration of methylphenidate with nicotine - there are presynaptic acetylcholine receptors on mesolimbic neurons - increased DA levels in an additive manner (201). This may provide a basis for apparent attempts at self-medication through cigarette smoking. Important for the distinction between the function of tonic and phasic activity, and its behavioural effect, Volkow's PET studies in humans show that methylphenidate-induced increases in DA are associated with an enhanced perception of a stimulus as salient (202). While such perception is clearly relevant for the interest in and motivation generated by such stimuli, it relativises the emphasis placed on mesolimbic reinforcement processes in the direction of the attentional mechanisms I have emphasised.

There is evidence for genetic variation in the production of more and less efficient DAT. The 10-repeat allele for DAT (3' variable number tandem repeat polymorphic site in 3 ' region of the gene SLC6A3) is reportedly over-active. To obtain this beneficial behavioural, attentional and biochemical response to methylphenidate it is advantageous not to be homozygous for the 10/10 repeat allele of DAT (203-208) even though the EEG of homozygotes is somewhat normalised after treatment $^{6}$ (206). Although there is modest reason for suggesting a biased transmission of the $10 / 10$ variant in $A D / H D(210,211)$, many studies do not find this - implying that we should be looking for other types of DAT variant.

As suggested above there is evidence for the involvement of the ventral striatum, thalamus and orbital-frontal cortex in discriminating reinforcement contingencies (or their saliency) in normal subjects (212)

\footnotetext{
${ }^{6}$ The opposite effect (increased theta power) on the magnetic form of the EEG after methylphenidate treatment was reported for a group of ADHD patents who had not been genotyped (209)
} 
and that the 10/10 allele is associated with size reduction of the nearby caudate nucleus (128). However, there is sparse evidence that methylphenidate is associated with changes of the aversion to delays. Yet, we have long known that the steep reinforcement gradient shown by the spontaneously hypertensive rat model of $A D / H D$ is improved after methylphenidate treatment (213). Immediate reinforcement was less effective and responses for delayed reinforcement were strengthened. The same effect of treatment was reported from a study of adults with a history of criminal behaviour (214). One presumes that the weak signal provided by a cued delay of reinforcement is amplified by the drug's effect on DA release. This seems to be supported by another PET study of normal adults from the Volkow team (215) showing that while the sight of food elicited no change in the dynamics of DA activity, there was a major response if the subjects had received a prior dose of methylphenidate. However, the apparent support from animal work is a bit difficult to reconcile with other rodent studies showing that chronic treatment in the pre- and peri-adolescent period resulted in less interest in natural rewards [e.g. sucrose, novelty and sex: (216)]. This qualification and the interpretation of Volkow's data would seem to put emphasis on the processing of the 'signal' rather than on incentive and motivation.

\section{Mesolimbic Pathway (5-HT)}

The previous section introduced the interactions of 5-HT with DA in regions innervated by the mesocortical projections. Such interactions are relevant in areas innervated by the mesolimbic system, and do concern the questions about impulsivity, of reinforcement mechanisms and motivation just addressed.
In $A D / H D$ children cognitive impulsivity measured by a reduced probability of inhibition in the stop-task, is associated with decreased affinity (increased $\mathrm{Kd}$ in platelets) of the 5-HT transporter (22): (figure 4) ${ }^{7}$. With regard to the reinforcement mechanisms, stimulants like amphetamine (therapeutic in $A D / H D$ ) and cocaine act presynaptically on DA transport. Both alter 5-HT dynamics. Indeed if the DA transporter is knocked out in rodents reinforcement measured by cocaine administration (217) or conditioned place preference to amphetamine (218) remains, - until a $5-\mathrm{HT}_{1}$ a antagonist is administered. Further, the sensitivity to reinforcement administered by intracranial self-stimulation to the hypothalamus is increased by treating the median raphe nucleus with a 5-HT1a agonist (219). Interactions between 5-HT and DA systems are central to considerations of cognitive impulsivity and the associated evaluation of reinforcement.

There is a large body of animal research that clearly shows the involvement of $5-\mathrm{HT}$ interactions with DA in the mediation of the mechanisms underlying the preferred choice of $A D / H D$ children for receiving immediate rather than delayed rewards. Measures taken with a dozen agents blocking NA and 5-HT uptake (but not DA uptake) show that there is an increased efficiency for obtaining water presented on a schedule of differential reinforcement at low rates of response [DRL: $(220,221)]$. A similar effect was seen in young adult

\footnotetext{
${ }^{7}$ Cognitive impulsivity should not be confused with the poor control of aggressive responses, often seen in ADHD children especially those with comorbid conduct disorder. For disruptive behaviour the association with the affinity of the transporter was the opposite (figure 4), consistent with a large literature on the role of 5-HT in aggression (22)
} 
Probability of respon se inhibition (stop signal $200 \mathrm{~ms}$ before) vs. Kd affinity (of p aroxetine binding)

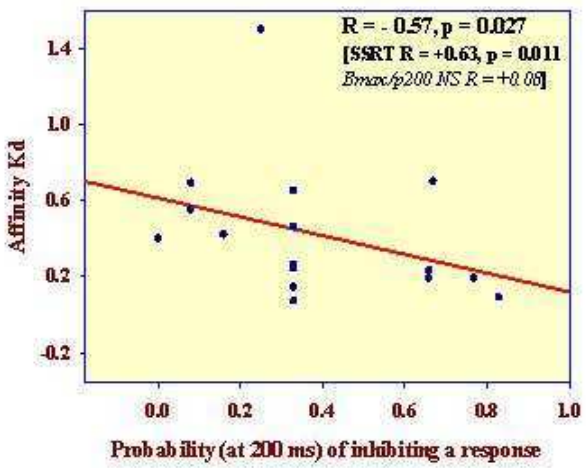

Probability of response inhibition (stop-signal $350 \mathrm{~ms}$ before) vs. Kd affinity (of paroxetine binding)

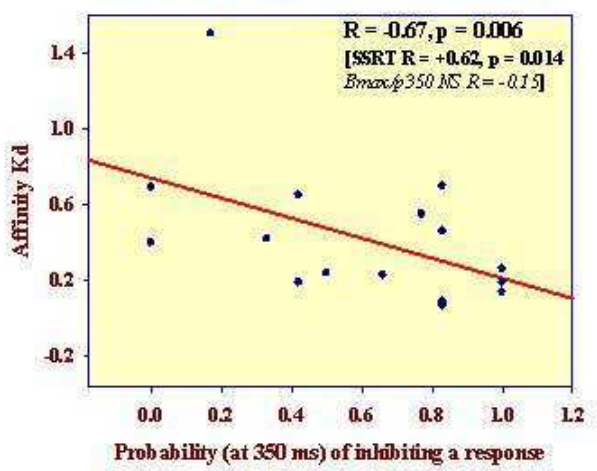

The affinity of the 5-HT transporter

vs. the probability of withholding a response (left)

vs. CBCL ratings of

externalising/aggressive behaviour (below)

in children with $\mathrm{AD} / \mathrm{HD}$
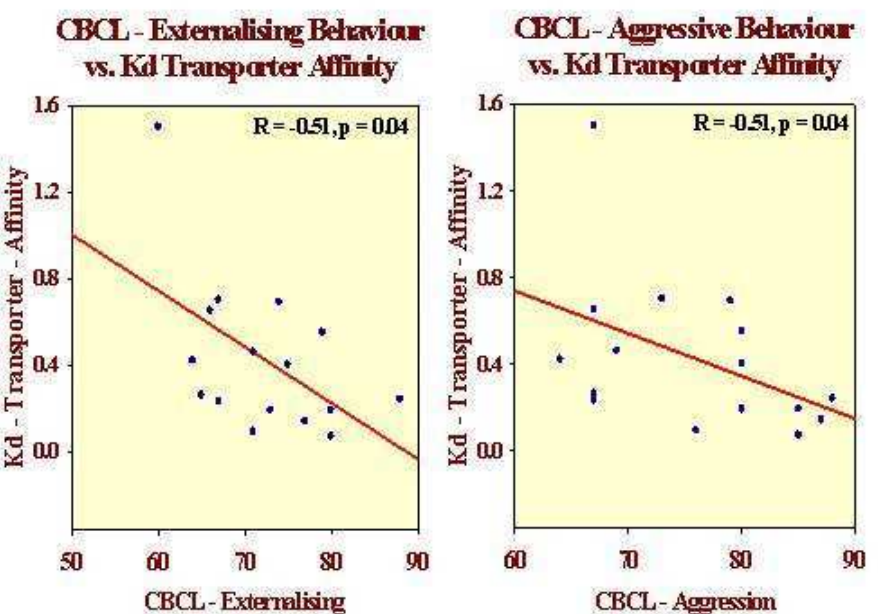

\section{Figure 4}

The relationship of the affinity $(\mathrm{Kd})$ of the 5-HT transporter on platelets sampled from children with $\mathrm{AD} / \mathrm{HD}$ with (left) their ability to withhold response if required on the Stop-task (stop-signal reaction time SSRT) - the lower the probability of inhibiting a response (i.e., the more impulsive) the higher the Kd (lower affinity: Bmax was unrelated). On the right the reverse relationship between increasing $\mathrm{Kd}$ and more aggressive behaviour is shown. [Modified after (22) and reproduced with the permission of Taylor/Francis].

criminals given paroxetine while performing a task where a short delay resulted in a small reward, but a longer delay gave more reinforcement (222). [It may be noted that sub-chronic paroxetine down regulates preand post-synaptic 5-HT1a sites in normal young adults (223)]. In confirmation, enhancing activity at the HT1a sites in animals leads to problems with delaying response for reinforcement $(224,225)$.
Enhancing activity at HT1b sites attenuates the effects of psychostimulants like amphetamine in decreasing impulsivity and promoting responses to targets (226), while HT2 antagonism may also lead to impulsive responding (227). Comparison between animals bred for high or low sensitivity to 5HT1a stimulation showed the latter with high response rates, and low reward rates on a DRL schedule (228): these effects were 
improved with reuptake inhibitors. Reduced 5-HT activity promoted the selection of the delayed but larger reward (229, 230). Recently thinking (and experiment) about these mechanisms led to the suggestion that while DA systems should be active during behavioural decisions requiring effort and concerning delay, 5-HT systems were needed for the latter (231).

Thus, overall, there is reason to believe that 5-HT plays a marked role in the sensory, reinforcement, inhibitory and motor processes that are disturbed in $\mathrm{AD} / \mathrm{HD}$. At least in relation to $5-\mathrm{HT}$ activity, the DA system seems to be hypoactive.

The status of peripheral and central nervous monoamine systems:

Measures of the elimination of monoamine metabolites are indirect indicators of transmitter activity. It is difficult to identify the sources of these metabolites. But it is of both basic and clinical interest that there is some broad support for the relative activities between the monoamines, and some associations for these ratios with measures of symptoms or cognitive activity in young subjects with or without $A D / H D$.

\section{NA metabolism:}

Levels of the metabolite MHPG (3methoxy-4-hydroxyphenyl glycol), possibly an indicator of resting NA metabolism, are reported to be unusually low in $A D / H D$ in $8 / 13$ studies (59). Raised levels of other metabolites such as NMN (normetanephrine) have been reported, possibly reflecting increased sympathetic activity $(17,179)$, as associated with the stress of a cognitive task $(17,232)$. Sub-chronic treatment with methylphenidate often results in further decreases of MHPG in peripheral catchments (233-238) that correlate with improvements in symptom ratings $(237,239)$. Speculatively, this may reflect a reduction of NA overflow resulting in the better control of $\mathrm{DA} / 5 \mathrm{HT}$ interactions via the high affinity alpha- 2 than the alpha-1 site that is more closely related to activity in stressful situations.

\section{DA metabolism:}

Pharmacological blocking of peripheral catecholamine breakdown shows that 15$20 \%$ of HVA may have a central origin. As a group levels are reported as normal, sometimes a bit low in CSF (240), plasma (241) and urine $(235,242)$. Psychostimulant treatment tends to lower HVA excretion (in urine, plasma and (SF), if not quite to the same extent as the effect on MHPG (179, $233,242,243)$. Shekim et al., $(235,236)$ reported a rate-dependent effect with high levels being lowered and low levels raised. Down-regulation has been reported to relate to decreases of symptoms, more especially for measures of hyperactivity than of attention (162, 240, 241, 244). Together these data suggest that in comparison with NA metabolism the DA system is relatively hyperactive (165), even if some indicators suggest that DA metabolic activity is lower than normal. For example, Konrad (17) reported that impulsive errors of commission on a CPT-ax task related to rates of eye-blinking, and hence indirectly DA activity. Further, signal detection measures on a test of sustained attention (CPTax) were inversely related to HVA in normal children: no such relationship was found in age-matched children with $A D / H D$ (16).

\section{5-HT metabolism:}

A markedly lower ratio of DA to 5-HT metabolites (HVA/5-HIAA) reported in $A D / H D$ subjects would be consistent with slightly lower DA and higher 5-HT metabolism (165). But this result has not been supported in all samples $(167,245)$. 
However, the increased 5-HIAA levels reported were shown to correlate closely and inversely with two quite separate measures of attentional ability, namely conditioned blocking and sensitivity (dprime) on the CPT-ax task $(16,164)$. These results along with those for the stop-task (see figure 3) are consistent with an overavailability of 5-HT in the synapses of children with $A D / H D$.

Could there be a simple explanation for the proposed relatively hyper-serotonergic (vs. DA) situation? Uzbekov (179) proposed one possibility. His laboratory found that while stimulant treatment (sydnocarb) reduced the high levels of 5-HIAA, Nmethyl-nicotinamide ( $\mathrm{N}$-mna) levels rose. $\mathrm{N}$ $\mathrm{mna}$ is the end product of the alternative metabolic pathway for the 5-HT precursor Ltryptophan. One may entertain the possibility that over activity of the indoleamine was pharmacologically diverted to an alternative metabolic route. This would be consistent with a psychostimulant induced reduction of 5-HT levels (246). The hypothesis is open to test.

\section{Conclusions:}

The diagnostic manuals maintain that $A D / H D$ incurs differentially a broad range of cognitive (inattention), motor (hyperactive) and impulsive (response inhibition) problems. The core of this was described some 50 years ago (247). The bases for these and related problems lie along a cerebellar - pontine/mesencephalic cerebro-cortical axis [cf. pathophysiological findings, (248)]. Recent experimental and pharmacological work points to a large contribution from the monoaminergic pathways originating in the mid/hind brain to the dysfunctions in the target areas innervated by dopamine (DA), noradrenaline (NA) and serotonin (5-HT). A significant proportion of these (dys)functions can be attributed to executive processes, the evaluation of stimuli and the reinforcement potentially associated with these events. Monoamine activity is discussed within the context of a dual-pathway theory of $A D / H D$ function (92). In this context mesocortical contributions to neuropsychological performance are described here for NA (with respect to DA) and mesolimbic contributions to reinforcement-related processes are described for 5-HT (with respect to DA). To divide the roles of the pathways in this way is useful but does tend to over simplify. Thus, different forms of impulsivity depend on mesolimbic and on mesocortical interactions. To summarise in terms of DA activity being proportionately higher than that for NA or lower than that for $5-\mathrm{HT}$ has a degree of validity but is a generalization masking some of the details of the mechanisms involved. The realisation of cognitive process in the form of adaptive behaviour necessarily incurs additional local GABAergic feedback, glutamatergic corticostriatal integration and moderation by cholinergic input.

\section{References}

1. American Psychiatric Association. 2000. Diagnostic and statistical manual of mental disorders: DSM-IV-TR. Washington, D.C.

2. Swanson JM, Sergeant JA, Taylor EA, Sonuga-Barke EJS, Jensen PS, Cantwell DP. 1998. Attention-deficit hyperactivity disorder and hyperkinetic disorder. Lancet 351:429-432.

3. Smith AB, Taylor EA. 2006. Response inhibition and hyperactivity in clinical and non-clinical populations: a meta-analysis using the stop task. In: Oades RD, editor. Progress in Attention-Deficit/ Hyper-activity Research. Hauppauge, New York: Nova Science Publishing Inc. In Press. 
4. Johnstone SJ, Barry RJ, Anderson JW. 2001. Topographic distribution and developmental time course of auditory event-related potentials in two subtypes of attention-deficit hyperactivity disorder. Int J Psychophysiol 42:73-94.

5. Levy F. 2004. Synaptic gating and ADHD: a biological theory of comorbidity of ADHD and anxiety. Neuropsychopharmacol 29:1589-1596.

6. Banaschewski $T$, Brandeis $D$, Heinrich $H$, Albrecht B, Brunner $E$, Rothenberger $A$. 2003. Association of ADHD and conduct disorder - brain electrical evidence for the existence of a distinct subtype. J Child Psychol Psychiat 44:356-376.

7. Rubia K, Asherson P, Taylor EA, Curran S. 2006. Association between the 7-repeat allele of the dopamine D4 receptor gene and specific impulsivity measures in attention deficit hyperactivity disorder (ADHD). In: Oades RD, editor. Progress in Attention-Deficit/Hyperactivity Disorder Research. Hauppauge, New York: Nova Science Publishing, Inc. p. In Press.

8. Clarke AR, Barry RJ, McCarthy R, Selikowitz M. 2002. EEG-defined subtypes of children with attention-deficit/hyperactivity disorder. Clin Neurophysiol 112:2098-2105.

9. Clarke AR, Barry RJ, McCarthy R, Selikowitz M, Croft RJ. 2002. EEG differences between good and poor responders to methylphenidate in boys with the inattentive type of attentiondeficit/hyperactivity disorder. Clin Neurophysiol 113:1191-1198.

10. Konrad K, Günther T, Hanisch C, Herpertz-Dahlmann B. 2004. Differential effects of methylphenidate on attentional functions in children with attentiondeficit/hyperactivity disorder. J Am Acad Child Adolesc Psychiat 43:191-198.
11. Castellanos FX, Tannock R. 2002. Neuroscience of attention-deficit/ hyperactivity disorder: the search for endophenotypes. Nature Reviews: Neuroscience 3:617-628.

12. Piek JP, Dyck MJ, Nieman A, Anderson A, Hay D, Smith LM, McCoy M, Hallmayer J. 2004. The relationship between motor coordination, executive functioning and attention in school aged children. Arch Clin Neuropsychol 19:1063-1076.

13. Russell VA, Oades RD, Tannock R, Auerbach J, Killeen PR, Johansen EB, Sagvolden T. 2006. Response variability in attention-deficit/hyperactivity disorder: a neuronal energetics hypothesis. BMC Behav Brain Funct in press.

14. Brodeur DA, Pond M. 2001. The development of selective attention in children with attention deficit hyperactivity disorder. J Abnorm Child Psychol 29:229239.

15. de Sonneville LMJ, Njiokiktjien C, Bos H. 1994. Methylphenidate and information processing. Part 1: Differentiation between responders and non-responders; Part 2: Efficacy in responders. J Clin Exp Neuropsychol 16:877-897.

16. Oades RD. 2000. Differential measures of sustained attention in children with attention-deficit/hyperactivity or tic disorders: relationship to monoamine metabolism. Psychiat Res 93:165-178.

17. Konrad K. 2006. Catecholamines and attentional function in children with ADHD. In: Oades RD, editor. Progress in AttentionDeficit Hyperactivity Disorder Research. Hauppauge, New York: Nova Science Publishers Inc. In Press.

18. Rubia K, Smith AB. 2006. Functional maturation of right inferior prefrontal cortex and anterior cingulate gyrus during 
inhibitory and self-monitoring functions. Hum Brain Mapp in press.

19. Wiersema JR, van der Meere JJ, Roeyers H. 2005. ERP correlates of impaired error monitoring in children with ADHD. J Neur Trans 112:1417-1430.

20. Sonuga-Barke EJS, Dalen L, Remington B. 2003. Do Executive Deficits and Delay Aversion Make Independent Contributions to Preschool Attention-Deficit/Hyperactivity Disorder Symptoms? J Am Acad Child Adolesc Psychiat 42:1335-1342.

21. Moeller FG, Barratt ES, Dougherty DM, Schmitz JM, Swann AC. 2001. Psychiatric aspects of impulsivity. Am J Psychiat 158:1783-1793.

22. Oades RD, Slusarek $M$, Velling $S$, Bondy B. 2002. Serotonin platelet-transporter measures in childhood attention-deficit/ hyperactivity disorder (ADHD): clinical versus experimental measures of impulsivity. World J Biol Psychiatry 3:96100.

23. Nigg JT, Blaskey LG, Huang-Pollock CL, Rappley MD. 2002. Neuropsychological executive functions and DSM-IV ADHD subtypes. J Am Acad Child Adolesc Psychiat 41:59-66.

24. Barry RJ, Clarke AR, McCarthy R, Selikowitz M, Brown CR. 2006. Event Related Potentials in Two DSM-IV Subtypes of Attention-Deficit/Hyperactivity Disorder: An investigation using a combined modality auditory/visual oddball task. In: Oades RD, editor. Progress in Attention-Deficit/ Hyperactivity Disorder Research. Hauppauge, New York: Nova Science Publishers, Inc. in press.

25. Brown CR, Clarke AR, Barry RJ, McCarthy R, Selikowitz M, Magee C. 2005. Event Related Potentials in AttentionDeficit/Hyperactivity Disorder of the
Predominantly-Inattentive type: An Investigation of EEG-Defined Subtypes. Int J Psychophysiol 58:94-107.

26. Oades RD, Dittmann-Balcar A, Schepker R, Eggers C. 1996. Auditory event-related potentials and mismatch negativity in healthy children and those with attentiondeficit- or Tourette-like symptoms. Biol Psychol 43:163-185.

27. Lazzaro I, Whitmont GE, Meares R, Clarke S. 2001. The modulation of late component event related potentials by prestimulus EEG theta activity in ADHD. Int J Neurosci 107:247-264.

28. Brandeis D, Banaschewski T, Baving L, Georgiewa P, Blanz B, Schmidt MH, Warnke $A$, Steinhausen $\mathrm{H}-\mathrm{C}$, Rothenberger $\mathrm{A}$, Scheuerpflug P. 2002. Multicenter P300 brain mapping of impaired attention to cues in hyperkinetic children. J Am Acad Child Psychiat 41:990-998.

29. Kemner C, Jonkman LM, Kenemans JL, Böcker KBE, Verbaten MN, van Engeland $\mathrm{H}$. 2004. Sources of auditory selective attention and the effects of methylphenidate in children with attention-deficit/ hyperactivity disorder. Biol Psychiat 55:776778.

30. Liotti M, Pliszka SR, Perez R, Kothmann D, Woldorff MG. 2005. Abnormal brain activity related to performance monitoring and error detection in children with ADHD. Cortex 41:377-388.

31. Steger J, Imhof K, Steinhausen H-C, Brandeis D. 2000. Brain mapping of bilateral interactions in attention deficit hyperactivity disorder and control boys. Clin Neurophysiol 111:1141-1156.

32. Kanemura H, Aihara M, Aoki S, Araki T, Nakazawa S. 2003. Development of the prefrontal lobe in infants and children: a 
three-dimensional magnetic resonance volumetric study. Brain Dev 25:195-199.

33. Huttenlocher PR, de Courten C, Garey LA, van der Loos H. 1982. Synaptogenesis in human visual cortex - evidence for synaptic elimination during normal development. Neurosci Lett 33:247-252.

34. O'Donnell S, Noseworthy MD, Levine B, Dennis M. 2005. Cortical thickness of the fronto-polar area in typically developing children and adolescents. Neuroimage 24:948-954.

35. Blanton RE, Levitt JG, Peterson JR, Sporty ML, Lee $M$, To $D$, Mormino EC, Thompson PM, McCracken JT, Toga AW. 2004. Gender differences in the left inferior frontal gyrus in normal children. Neuroimage 22:626-636.

36. Sowell ER, Jernigan TL. 1998. Further MRI evidence of late brain maturation: limbic volume increases and changing asymmetries during childhood and adolescence. Dev Neuropsychol 14:599-617.

37. Sowell ER, Trauner DA, Gamst A, Jernigan TL. 2002. Development of cortical and subcortical brain structures in childhood and adolescence: a structural MRI study. Dev Med Child Neurol 44:4-16.

38. Gogtay N, Giedd JN, Lusk L, Hayashi KM, Greenstein D, Vaituzis AC, Nugent TF, Herman DH, Clasen LS, Toga AW, Rapoport $\mathrm{JL}$, Thompson PM. 2004. Dynamic mapping of human cortical development during childhood through early adulthood. Proc Natl Acad Sci (USA) 101:8174-8179.

39. Wild-Wall N, Oades RD, Juran SA. 2005. Maturation processes in automatic change detection as revealed by event-related brain potentials and dipole source localization: Significance for adult AD/HD. Int J Psychophysiol 58:34-46.

40. Bartzokis G, Nuechterlein KH, Gitlin M,
Rogers S, Mintz J. 2003. Dysregulated brain development in adult men with schizophrenia: a magnetic resonance imaging study. Biol Psychiat 53:412-421.

41. Lambert J, Bard C. 2005. Acquisition of visuo-manual skills and improvement of information processing capacities in 6 - to 10-year-old children performing a $2 \mathrm{D}$ pointing task. Neurosci Lett 377:1-6.

42. Rival C, Ceyte H, Olivier I. 2005. Developmental changes of static standing balance in children. Neurosci Lett 376:133136.

43. Rueda MR, Fan J, McCandliss BD, Halperin JD, Gruber DB, Lercari LP, Posner MI. 2004. Development of attentional networks in childhood. Neuropsychologia 42:1029-1040.

44. Spear L. 2000. The adolescent brain and age-related behavioral manifestations. Neurosci Biobehav Rev 24:417-463.

45. Luna B, Garver KE, Urban TA, Lazar NA, Sweeney JA. 2004. Maturation of Cognitive Processes from Late Childhood to Adulthood. Child Dev 75:1357-1372.

46. Casey BJ, Trainor RJ, Orendi JL, Schubert $A B$, Nystrom LE, Giedd JN, Castellanos FX, Haxby JV, Noll DC, Cohen JD, Forman SD, Dahl RE, Rapoport JL. 1997. A developmental functional MRI study of prefrontal activation during performance of a go-no-go task. J Cog Neurosci 9:835-847.

47. Ladouceur CD, Dahl RE, Carter CS. 2004. ERP correlates of action monitoring in adolescence. Ann N Y Acad Sci 1021:329336.

48. Sharma A, Kraus N, McGee TJ, Nicol TG. 1997. Developmental changes in P1 and N1 central auditory responses elicited by consonant-vowel syllables. EEG Clin Neurophysiol 104:540-545. 
49. Marshall PJ, Bar-Haim Y, Fox NA. 2003. The development of P50 suppression in the auditory event-related potential. Int J Psychophysiol 51:135-141.

50. Freedman R, Adler LE, Waldo MC. 1987. Gating of the auditory evoked potential in children and adults. Psychophysiol 24:223227.

51. Oades RD, Dittmann-Balcar A, Zerbin D. 1997. Development and topography of auditory event-related potentials, mismatch and processing negativity from 8 to 22 years of age. Psychophysiol 34:677-693.

52. Albrecht R, von Suchodoletz W, Uwer R. 2000. The development of auditory evoked dipole source activity from childhood to adulthood. Clin Neurophysiol 111:22682276.

53. Polich J, Ladish C, Burns T. 1990. Normal variation of P300 in children: age, memory span, and head size. Int J Psychophysiol 9:237-248.

54. Enoki H, Sanada S, Yoshinaga H, Oka E, Ohtahara S. 1993. The effects of age on the N200 component of the auditory eventrelated potentials. Cogn Brain Res 1:161167.

55. Oades RD, Halliday GM. 1987. The ventral tegmental (A 10$)$ system. Neurobiology I: anatomy and connectivity. Brain Res Rev 12:117-165.

56. Lewis DA. 2003. The catecholamine innervation of primate cerebral cortex. In: Solanto MV, Arnsten AFT, Castellanos FX, editors. Stimulant drugs and ADHD: basic and clinical neuroscience. Oxford: Oxford University Press. p. 77-103.

57. Loughlin SE, Foote SL, Bloom FE. 1986. Efferent projections of nucleus locus coeruleus: topographic organization of cells of origin demonstrated by three- dimensional reconstruction. Neurosci 18:291-306.

58. Svensson TH. 2003. a-Adrenoceptor modulation hypothesis of antipsychotic atypicality. Prog Neuropsychopharmacol Biol Psychiat 27:1145-1158.

59. Oades RD. 2005. The Role of Norepinephrine and Serotonin in ADHD. In: Gozal D, Molfese DL, editors. Attention Deficit Hyperactivity Disorder: From Genes to Animal Models to Patients. Tootawa, N.Y.: Humana Press. p. 97-130.

60. Lewis DA, Foote SL, Goldstein M, Morrison JH. 1988. The dopaminergic innervation of monkey prefrontal cortex: a tyrosine hydroxylase immunohistochemical study. Brain Res 449:225-243.

61. Lucas G, Spampinato U. 2000. Role of striatal serotonin $_{2 A}$ and serotonin $2 C$ receptor subtypes in the control of the in vivo dopamine outflow in the rat striatum. J Neurochem 74:693-701.

62. Gobert A, Rivet J-M, Audinot V, Newman-Tancredi A, Cistarelli L, Millan MJ. 1998. Simultaneous quantification of serotonin, dopamine and noradrenaline levels in single frontal cortex dialysates of freely-moving rats reveals a complex pattern of reciprocal auto- and heteroceptor-mediated control of release. Neurosci 84:413-429.

63. De Haes JI, Bosker FJ, Van Waarde A, Pruim J, Willemsen AT, Vaalburg W, Den Boer JA. 2002. 5-HT1A receptor imaging in the human brain: Effect of tryptophan depletion and infusion on [18F]MPPF binding. Synapse 46:108-115.

64. Wright DE, Seroogy KB, Lundgren $\mathrm{KH}$, Davis BM, Jennes L. 1995. Comparative localization of serotonin $1 \mathrm{~A}, 1 \mathrm{C}$ and 2 receptor subtype mRNAs in rat brain. J comp Neurol 351:357-373. 
65. Kalsbeek A. 1989. The role of dopamine in the development of the rat prefrontal cortex. Amsterdam: Krips Repro meppel (Acad. proefschrift).

66. Meng SZ, Ozawa Y, Itoh M, Takashima S. 1999. Development and age-related changes of dopamine transporter, and dopamine D1 and D2 receptors in human basal ganglia. Brain Res 843:136-144.

67. Seeman P, Bzowej NH, Guan HC, Bergeron C, Becker LE, Reynolds GP, Bird $E D$, Riederer $P$, Jellinger $K$, Watanabe $S$, Tourtellotte WW. 1987. Human brain dopamine receptors in children and aging adults. Synapse 1:399-404.

68. Andersen SL, Teicher MH. 2000. Sex differences in dopamine receptors and their relevance to ADHD. Neurosci Biobehav Rev 24:137-141.

69. Rodriguez M, Martin L, Santana C. 1994. Ontogenic development of brain asymmetry in dopaminergic neurons. Brain Res Bull 33:163-171.

70. Lambe EK, Krimer LS, Goldman-Rakic PS. 2000. Differential postnatal development of catecholamine and serotonin inputs to identified neurons in prefrontal cortex of Rhesus monkey. J Neurosci 20:8780-8787.

71. Oades RD, Röpcke B, Schepker R. 1996. A test of conditioned blocking and its development in childhood and adolescence: relationship to personality and monoamines metabolism. Dev Neuropsychol 12:207-230.

72. Verney C, Milosevic A, Alvarez C, Berger B. 1993. Immunocytochemical evidence of well-developed dopaminergic and noradrenergic innervations in the frontal cerebral cortex of human fetuses at midgestation. J Comp Neurol 336:331-344.

73. Zecevic N, Verney C. 1995. Development of the catecholamine neurons in human embryos and fetuses, with special emphasis on the innervation of the cerebral cortex. J comp Neurol 351:509-535.

74. Tomasini R, Kema IP, Muskiet FAJ, Meiborg G, Staal MJ, Go KG. 1997. Catecholaminergic development of fetal ventral mesencephalon: characterization by high-performance liquid chromatography with electrochemical detection and immunohistochemistry. Exp Neurol 145:434-441.

75. Konradi C, Kornhuber J, Sofic E, Heckers S, Riederer P, Beckmann H. 1992. Variations of monoamines and their metabolites in the human brain putamen. Brain Res 579:285290.

76. Neddens J, Dawirs RR, Bagorda F, Busche A, Horstmann S, Teuchert-Noodt G. 2004. Postnatal maturation of cortical serotonin lateral asymmetry in gerbils is vulnerable to both environmental and pharmacological epigenetic challenges. Brain Res 1021:200-208.

77. Arnsten AFT. 2006. Noradrenergic Actions in Prefrontal Cortex: Relevance to ADHD. In: Oades RD, editor. Progress in Attention-Deficit Hyperactivity Disorder Research. Hauppauge, New York: Nova Science Publishers Inc. p. in press.

78. Beane M, Marrocco RT. 2005. Norepinephrine and acetylcholine mediation of the components of reflexive attention: implications for attention deficit disorders. Prog Neurobiol 74:167-181.

79. Oades RD. 1985. The role of noradrenaline in tuning and dopamine in switching between signals in the CNS. Neurosci Biobehav Rev 9:261-283.

80. Rajkowski J, Majczynski H, Clayton E, Aston-Jones GS. 2004. Activation of monkey locus coeruleus neurons varies with difficulty and performance in a target detection task. J Neurophysiol 92:361-371. 
81. Carli M, Samanin R. 2000. The $5-\mathrm{HT}_{1 \mathrm{~A}}$ receptor agonist 8-OH-DPAT reduces rats' accuracy of attentional performance and enhances impulsive responding in a fivechoice serial reaction time task: role of presynaptic 5- $\mathrm{HT}_{1 \mathrm{~A}}$ receptors. Psychopharmacol 149:259-268.

82. Dalley JW, Theobald DE, Eagle DM, Passetti F, Robbins TW. 2002. Deficits in impulse control associated with tonicallyelevated serotonergic function in rat prefrontal cortex. Neuropsychopharmacol 26:716-728.

83. Kavoussi R, Armstead P, Coccaro EF. 1997. The neurobiology of impulsive aggression. Psychiat Clin N Am 20:395-403.

84. Winter JC, Eckler JR, Doat MM, Rabin RA. 2002. The effects of acute and subchronic treatment with fluoxetine and citalopram on stimulus control by DOM. Pharmacol Biochem Behav 74:95-101.

85. Aglioti S, Smania N, Barbieri C, Corbetta M. 1997. Influence of stimulus salience and attentional demands on visual search patterns in hemi-spatial neglect. Brain Cogn 34:388-403.

86. Malapani C, Pillon B, Dubois B, Agid Y. 1994. Impaired simultaneous cognitive task performance in Parkinson's disease: a dopamine-related dysfunction. Neurol 44:319-326.

87. Oades RD. 1997. Stimulus dimension shifts in patients with schizophrenia, with and without paranoid hallucinatory symptoms, or obsessive compulsive disorder: strategies, blocking and monoamine status. Behav Brain Res 88:115132.

88. McCormick DA, Pape HC, Williamson A. 1991. Actions of norepinephrine in the cerebral cortex and thalamus: implications for function of the central noradrenergic system. Prog Brain Res 88:293-305.

89. Devoto P, Flore G, Pira L, Longu G, Gessa GL. 2004. Mirtazapine-induced co-release of dopamine and noradrenaline from noradrenergic neurons in the medial prefrontal and occipital cortex. Eur J Pharmacol 487:105-111.

90. Lanau F, Zenner MT, Civelli O, Hartman DS. 1997. Epinephrine and norepinephrine act as potent agonists at the recombinant human dopamine D4 receptor. J Neurochem 68:804-812.

91. Auclair A, Cotecchia S, Glowinski J, Tassin J-P. 2002. D-amphetamine fails to increase extracellular dopamine levels in mice lacking alpha $1 b$-adrenergic receptors: relationship between functional and nonfunctional dopamine release. J Neurosci 22:9150-9154.

92. Sonuga-Barke EJS. 2005. Causal models of attention-deficit/hyperactivity disorder: from common simple deficits to multiple developmental pathways. Biol Psychiat 57:1231-1238.

93. Sergeant JA, Oosterlaan J, van der Meere JJ. 1999. Information processing in attention-deficit/hyperactivity disorder. In: Quay HC, Hogan AE, editors. Handbook of disruptive behavior disorders. New York: Plenum Press. p. 75-104.

94. Barkley RA. 1997. Behavioral inhibition, sustained attention and executive functions: constructing a unifying theory of ADHD. Psychol Bull 121:65-94.

95. Quay HC. 1997. Inhibition and attention deficit hyperactivity disorder. J Abnorm Child Psychol 25:7-13.

96. Sagvolden T, Johansen EB, Aase $H$, Russell VA. 2005. A dynamic developmental theory of attention-deficit/hyperactivity disorder (ADHD) predominantly hyperactive /impulsive and combined subtypes. Behav 
Brain Sci in press.

97. Luman $M$, Oosterlaan J, Sergeant JA. 2005. The impact of reinforcement contingencies on AD/HD: $A$ review and theoretical appraisal. Clin Psychol Rev 25:183-213.

98. Casey BJ, Castellanos FX, Giedd JN, Marsh WL, Hamburger SD, Schubert $A B$, Vauss YC, Vaituzis AC, Dickstein DP, Sarfatti SE, Rapoport JL. 1997. Implication of right fronto-striatal circuitry in response inhibition and attention-deficit / hyperactivity disorder. J Am Acad Child Adolesc Psychiat 36:374-383.

99. Rubia K, Overmeyer S, Taylor EA, Brammer MJ, Williams SCR, Simmons A, Bullmore ET. 1999. Hypofrontality in attention deficit hyperactivity disorder during higher-order motor control: a study with functional MRI. Am J Psychiat 156:891896.

100. Rubia K, Smith AB, Brammer MJ, Toone BK, Taylor EA. 2004. Medication-naive adolescents with attention-deficit hyperactivity disorder show abnormal brain activation during inhibition and error detection. Am J Psychiat in press.

101. Rubia K, Smith AB, Brammer MJ, Toone B, Taylor E. 2005. Abnormal Brain Activation during Inhibition and Error Detection in Medication-Naive Adolescents with ADHD. Am J Psychiat 162:1067-1075.

102. Vaidya CJ, Bunge SA, Dudukovic NM, Zalecki CA, Elliiott GR, Gabrieli DE. 2005. Altered Neural Substrates of Cognitive Control in Childhood ADHD: Evidence From Functional Magnetic Resonance Imaging. Am J Psychiat 162:1605-1613.

103. Bunge SA, Dudokovic NM, Thomason MA, Vaidya CJ, Gabrieli JDE. 2002. Immature frontal lobe contributions to cognitive control in children: evidence from fMRI.
Neuron 17:301-311.

104. Aron AR, Fletcher PC, Bullmore ET, Sahakian BJ, Robbins TW. 2003. Stop-signal inhibition disrupted by damage to right inferior frontal gyrus in humans. Nature Neurosci 6:115-116.

105. Bush G, Frazier JA, Seidman L, Whalen PJ, Jenike MA, Rosen BR, Biederman J. 1999. Anterior cingulate cortex dysfunction in attention-deficit/hyperactivity disorder revealed by $\mathrm{fMRI}$ and the Counting Stroop. Biol Psychiat 45:1542-1552.

106. Durston S. 2003. A review of the biological bases of ADHD: what have we learned from imaging studies? Ment Retard Dev Disabil Res Rev 9:184-195.

107. Durston S, Hulshoff Pol HE, Schnack HG, Buitelaar J, Steenhuis MP, Minderaa RB, Kahn RS, van Engeland H. 2004. Magnetic Resonance Imaging of Boys with AttentionDeficit/Hyperactivity Disorder and Their Unaffected Siblings. J Am Acad Child Adolesc Psychiat 43:332-340.

108. Castellanos FX, Giedd JN, Marsh WL, Hamburger SD, Vaituzis AC, Dickstein DP, Sarfatti SE, Vauss YC, Snell JW, Lange N, Kaysen D, Krain AL, Ritchie GF, Rajapakse JC, Rapoport JL. 1996. Quantitative brain magnetic resonance imaging in attentiondeficit hyperactivity disorder. Arch Gen Psychiat 53:607-616.

109. Aron AR, Monsell S, Sahakian BJ, Robbins TW. 2004. A componential analysis of task-switching deficits associated with lesions of left and right frontal cortex. Brain 127:1561-1573.

110. Aron AR, Dowson JH, Sahakian BJ, Robbins TW. 2003. Methylphenidate improves response inhibition in adults with attention-deficit/hyperactivity disorder. Biol Psychiat 54:1465-1468.

111. Cepeda NJ, Cepeda ML, Kramer AF. 
2000. Task switching and attention deficit hyperactivity disorder. J Abnorm Child Psychol 28:213-226.

112. Kramer AF, Cepeda NJ, Cepeda ML. 2001. Methylphenidate effects on task switching performance in attentiondeficit/hyperactivity disorder. J Am Acad Child Adolesc Psychiat 40:1277-1284.

113. Schweitzer JB, Faber TL, Grafton ST, Tune LE, Hoffman JM, Kilts CD. 2000. Alterations in the functional anatomy of working memory in adult attention deficit hyperactivity disorder. Am J Psychiat 157:278-280.

114. Ernst $M$, Kimes AS, London ED, Matochik JA, Eldreth D, Tata S, Contoreggi C, Leff M, Bolla K. 2003. Neural substrates of decision making in adults with attention deficit hyperactivity disorder. Am J Psychiat 160:1061-1070.

115. Schweitzer JB, Lee DO, Hanford RB, Zink CF, Ely TD, Tagamets MA, Hoffman JM, Grafton ST, Kilts CD. 2004. Effect of methylphenidate on executive functioning in adults with attention-deficit/hyperactivity disorder: Normalization of behavior but not related brain activity. Biol Psychiat 56:597606.

116. Volkow ND, Fowler JS, Wang GJ, Ding YS, Gatley SJ. 2002. Role of dopamine in the therapeutic and reinforcing effects of methylphenidate in humans: results from imaging studies. Eur Neuropsychopharmacol 12:557-566.

117. Volkow ND, Wang G-J, Fowler JS, Telang F, Maynard L, Logan J, Gatley SJ, Pappas N, Wong C, Vaska P, Zhu W, Swanson JM. 2004. Evidence That Methylphenidate Enhances the Saliency of a Mathematical Task by Increasing Dopamine in the Human Brain. Am J Psychiat 161:1173-1180.
118. Volkow ND, Wang G-J, Ma Y, Fowler JS, Wong C, Ding Y-S, Hitzemann RJ, Swanson JM, Kalivas PW. 2005. Activation of Orbital and Medial Prefrontal Cortex by Methylphenidate in Cocaine-Addicted Subjects But Not in Controls: Relevance to Addiction. J Neurosci 25:3932-3939.

119. Volkow ND, Wang G-Y, Fowler JS, Hitzemann RJ, Gatley J, Ding Y-S, Wong C, Pappas N. 1998. Differences in regional brain metabolic responses between single and repeated doses of methylphenidate. Psychiat Res (Neuroimaging) 83:29-36.

120. Volkow ND, Logan J, Fowler JS, Wang G-J, Gur RC, Wong C, Felder C, Gatley J, Ding Y-S, Hitzemann RJ, Pappas N. 2000. Association between age-related decline in brain dopamine activity and impairment in frontal and cingulate metabolism. Am J Psychiat 157:75-80.

121. Ernst M, Zametkin AJ, Matochik JA, Jons PH, Cohen RM. 1998. DOPA decarboxylase activity in attention deficit hyperactivity disorder adults. A [fluorine-18] fluorodopa positron emission tomography study. J Neurosci 18:5901-5907.

122. Ernst M, Zametkin AJ, Matochik JA, Pascualvaca D, Jons PH, Cohen RM. 1999. High midbrain [18F] DOPA accumulation in children with attention deficit hyperactivity disorder. Am J Psychiat 156:1209-1215.

123. Bellgrove MA, Domschke K, Hawi Z, Kirley A, Mullins C, Robertson IH, Gill M. 2005. The methionine allele of the COMT polymorphism impairs prefrontal cognition in children and adolescents with ADHD. Exp Brain Res 163:352-360.

124. Mullins C, Bellgrove MA, Gill $M$, Robertson IH. 2005. Variability in Time Reproduction: Difference in ADHD Combined and Inattentive Subtypes. J Am Acad Child Adolesc Psychiat 44:169-176. 
125. Sunohara GA, Roberts $W$, Malone MA, Schachar RJ, Tannock R, Basile VS, Wigal T, Wigal SB, Schuck S, Moriarty J, Swanson JM, Kennedy JL, Barr CL. 2000. Linkage of the dopamine D4 receptor gene and attentiondeficit/hyperactivity disorder. J Am Acad Child Adolesc Psychiat 39:1537-1542.

126. Leung PWL, Lee $C C$, Hung SF, Ho TP, Tang CP, Kwong SL, Leung SY, Yuen ST, LiehMak F, Oosterlaan J, Grady D, Harxhi A, Ding YC, Chi HC, Flodman P, Schuck S, Spence MA, Moyzis R, Swanson JM. 2005. Dopamine Receptor D4 (DRD4) Gene in Han Chinese Children with AttentionDeficit/Hyperactivity Disorder (ADHD): Increased Prevalence of the 2-Repeat Allele. Am J Med Genet 133B:54-56.

127. Swanson JM, Oosterlaan J, Murias M, Schuck S, Spence AA, Wasdell M, Ding Y, Chi H-C, Smith M, Mann M, Carlson C, Kennedy $J \mathrm{~L}$, Sergeant JA, Leung $P$, Zhang $Y-P$, Sadeh $A$, Chen C, Whalen CK, Babb KA, Moyzis R, Posner MI. 2001. Attention deficit/ hyperactivity disorder children with a 7repeat allele of the dopamine receptor D4 gene have extreme behavior but normal performance on critical neuropsychological tests of attention. Proc Natl Acad Sci (USA) 97:4754-4759.

128. Durston S, Fossella JA, Casey BJ, Hulshoff Pol HE, Galvan A, Schnack HG, Steenhuis MP, Minderaa RB, Buitelaar JK, Kahn RS, van Engeland H. 2005. Differential effects of DRD4 and DAT1 genotype on fronto-striatal gray matter volumes in a sample of subjects with attention deficit hyperactivity disorder, their unaffected siblings, and controls. Mol Psychiat 10:678685.

129. Durston S, Fossella JA, Casey BJ. 2006. Neuroimaging as an approach to the Neurobiology of ADHD. In: Oades RD, editor. Progress in Attention-Deficit Hyperactivity
Research. Hauppauge, New York: Nova Science Publishers Inc. In Press.

130. Burnette WB, Bailey MD, Kukoyi S, Blakely RD, Trowbridge CG, Justice JB. 1996. Human norepinephrine transporter kinetics using rotating disk electrode voltammetry. Anal Chem 68:2932-2938.

131. Devoto P, Flore, Pani L, Gessa GL. 2001. Evidence for co-release of noradrenaline and dopamine from noradrenergic neurons in the cerebral cortex. Mol Psychiat 6:657664.

132. Biederman J, Spencer T. 1999. Attention-deficit/hyperactivity disorder (ADHD) as a noradrenergic disorder. Biol Psychiat 46:1234-1242.

133. Madras BK, Miller GM, Fischman AJ. 2005. The dopamine transporter and attention-deficit/hyperactivity disorder. Biol Psychiat 57:1397-1409.

134. Bobb AJ, Addington AM, Sidransky E, Gornick MC, Lerch JP, Greenstein DK, Clasen LS, Sharp WS, Inoff-Germain G, Wavrant-De Vrie'ze F, Arcos-Burgos M, Straub RE, Hardy JA, Castellanos FX, Rapoport JL. 2005. Support for Association between ADHD and Two Candidate Genes: NET1 and DRD1. Am J Med Genet 134B:67-72.

135. Yang L, Wang Y-F, Li JMS, Faraone SV. 2004. Association of Norepinephrine Transporter Gene with Methylphenidate Response. J Am Acad Child Adolesc Psychiat 43:1154-1158.

136. Xu X, Knight J, Brookes K, Mill J, Sham P, Craig I, Taylor E, Asherson P. 2005. DNA Pooling Analysis of 21 Norepinephrine Transporter Gene SNPs with Attention Deficit Hyperactivity Disorder: No Evidence for Association. Am J Med Genet 134B:115118.

137. De Luca V, Muglia P, Jani U, Kennedy JL. 2004. No evidence of linkage or association 
between the norepinephrine transporter (NET) gene Mnll polymorphism and adult ADHD. Am J Med Genet 124B:38-40.

138. Barr CL, Kroft J, Feng $Y$, Wigg K, Roberts W, Malone M, Ickowicz A, Schachar RJ, Tannock R, Kennedy JL. 2002. The norepinephrine transporter gene and attention-deficit hyperactivity disorder. Am J Med Genet 114:255-259.

139. Michelson D, Adler L, Spencer T, Reimherr FW, West SA, Allen AJ, Kelsey D, Wernicke J, Dietrich A, Milton DR. 2003. Atomoxetine in adults with ADHD: two randomized, placebo-controlled studies. Biol Psychiat 53:211-220.

140. Roman T, Schmitz M, Polanczyk GV, Eizirik M, Rohde LA, Hutz MH. 2003. Is the ? $2 a$ adrenergic receptor gene (ADRRA2A) associated with attention-deficit/ hyperactivity disorder? Am J Med Genet 120B:116-120.

141. Hawi Z, Lowe $N$, Kirley $A$, Nöthen $M$, Greenwood T, Kelsoe J, Fitzgerald M, Gill M. 2003. Linkage disequilibrium mapping at DAT1, DRD5 and DBH narrows the search for ADHD susceptibility alleles at these loci. Mol Psychiat 8:299-308.

142. Park L, Nigg JT, Waldman ID, Nummy KA, Huang-Pollock C, Rappley M, Friderici KH. 2004. Associations and linkage of ?-2A adrenergic receptor gene polymorphisms with childhood ADHD. Mol Psychiat doi:10.1038/sj.mp.4001605:1-9.

143. Wang M, Tang ZX, Li BM. 2004. Enhanced visuomotor associative learning following stimulation of alpha 2Aadrenoceptors in the ventral prefrontal cortex in monkeys. Brain Res 1024:176-182.

144. Wang M, Ji JZ, Li BM. 2004. The alpha(2A)-adrenergic agonist guanfacine improves visuomotor associative learning in monkeys. Neuropsychopharmacol 29:86-92.
145. Ma CL, Qi XL, Peng JY, Li BM. 2003. Selective deficit in no-go performance induced by blockade of prefrontal cortical alpha 2-adrenoceptors in monkeys. NeuroReport 14:1013-1016.

146. Ma C-L, Arnsten AFT, Li B-M. 2005. Locomotor hyperactivity induced by blockade of prefrontal cortical $a_{2}-$ adrenoceptors in monkeys. Biol Psychiat 57:192-195.

147. Clarke AR, Barry RJ, McCarthy R, Selikowitz M. 2006. EEG predictors of good response to Imipramine Hydrochloride in children with Attention Deficit/Hyperactivity Disorder. In: Oades RD, editor. Progress in Attention-Deficit/Hyperactivity Disorder Research. Hauppauge, NY: Nova Science Publishers, Inc. in press.

148. Hermens DF, Williams LM, Clarke S, Kohn M, Cooper N, Gordon E. 2005. Responses to methylphenidate in adolescent $\mathrm{AD} / \mathrm{HD}$ : Evidence from concurrently recorded autonomic (EDA) and central (EEG and ERP) measures. Int J Psychophysiol 58:21-33.

149. Sangal RB, Sangal JM. 2005. Attentiondeficit/hyperactivity disorder: cognitive evoked potential (P300) amplitude predicts treatment response to atomoxetine. Clin Neurophysiol 116:640-647.

150. Klorman R, Brumaghim JT. 1991. Stimulant drugs and ERPs. EEG Clin Neurophysiol suppl.42:135-141.

151. Seifert J, Scheuerpflug P, Zillessen K-E, Fallgatter AJ, Warnke A. 2003. Electrophysiological investigation of the effectiveness of methylphenidate in children with and without ADHD. J Neur Trans 110:821-829.

152. Lazzaro I, Anderson J, Gordon E, Clarke S, Leong J, Meares R. 1997. Single trial variability within the P300 (250-500 ms) 
processing window in adolescents with attention deficit hyperactivity disorder. Psychiat Res 73:91-101.

153. Jonkman LM, Kemner C, Verbaten MN, Koelega HS, Camfferman G, van der Gaag RJ, Buitelaar JK, van Engeland H. 1997. Effects of methylphenidate on event-related potentials and performance of attentiondeficit hyperactivity disorder children in auditory and visual selective attention tasks. Biol Psychiat 41:690-702.

154. Jonkman LM, Kemner C, Verbaten MN, van Engeland $H$, Camfferman $G$, Buitelaar JK, Koelega HS. 2000. Attentional capacity, a probe ERP study: differences between children with attention-deficit hyperactivity disorder and normal control children and effects of methylphenidate. Psychophysiol 37:334-346.

155. Prichep LS, Sutton S, Hakerem G. 1976. Evoked potentials in hyperkinetic and normal children under certainty and uncertainty: a placebo and methylphenidate study. Psychophysiol 13:419-428.

156. Broyd SJ, Johnstone SJ, Barry RJ, Clarke AR, McCarthy R, Selikowitz M, Lawrence CA. 2005. The effect of methylphenidate on response inhibition and the event-related potential of children with Attention Deficit/ Hyperactivity Disorder. Int J Psychophysiol 58:47-58.

157. Gehlert DR, Schober DA, HemrickLuecke SK, Kushinski J, Howbert JJ, Robertson DW, Fuller RW, Wong DT. 1995. Novel halogenated analogs of tomoxetine that are potent and selective inhibitors of norepinephrine uptake in brain. Neurochem Int 26:47-52.

158. Nocjar C, Roth BL, Pehek EA. 2002. Localization of $5-\mathrm{HT}(2 \mathrm{~A})$ receptors on dopamine cells in subnuclei of the midbrain A10 cell group. Neurosci 111:163-176.
159. Di Giovanni G, Di Matteo V, Di Mascio M, Esposito E. 2000. Preferential modulation of mesolimbic vs. nigrostriatal dopaminergic function by serotonin $2 c / 2 b$ receptor agonists: a combined in vivo electrophysiological and microdialysis study. Synapse 35:53-61.

160. Di Matteo V, Cacchio M, Di Giulio C, Esposito E. 2002. Role of serotonin (2C) receptors in the control of brain dopaminergic function. Pharmacol Biochem Behav 71:727-734.

161. Hutson $\mathrm{PH}$, Barton $\mathrm{CL}$, Jay $\mathrm{M}$, Blurton $\mathrm{P}$, Burkamp F, Clarkson R, Bristow LJ. 2000. Activation of mesolimbic dopamine function by phencyclidine is enhanced by $5-\mathrm{HT}_{2 \mathrm{C} / 2 \mathrm{~B}}$ receptor antagonists: neurochemical and behavioural studies. Neuropharmacol 39: 2318-2328.

162. Castellanos FX, Elia J, Kruesi MJP, Marsh WL, Gulotta CS, Potter WZ, Ritchie GF, Hamburger SD, Rapoport JL. 1996. Cerebrospinal fluid homovanillic acid predicts behavioral response to stimulants in 45 boys with attention deficit/ hyperactivity disorder. Neuropsychopharmacol 14:125-137.

163. Rogers RD, Blackshaw AJ, Middleton HC, Matthews K, Hawtin K, Crowley C, Hopwood A, Wallace C, Deakin JFW, Sahakian BJ, Robbins TW. 1999. Tryptophan depletion impairs stimulus reward learning while methylphenidate disrupts attentional control in healthy young adults: implications for the monoaminergic basis of impulsive behaviour. Psychopharmacol 146:482-491.

164. Oades RD, Müller BW. 1997. The development of conditioned blocking and monoamine metabolism in children with attention-deficit-hyperactivity disorder or complex tics and healthy controls: an exploratory analysis. Behav Brain Res 88:95102. 
165. Oades RD. 2002. Dopamine may be 'hyper' with respect to noradrenaline metabolism, but 'hypo' with respect to serotonin metabolism in children with ADHD. Behav Brain Res 130:97-101.

166. Rubia K, Lee F, Cleare AJ, Tunstall N, Fu CHY, Brammer M, McGuire PK. 2004. Tryptophan depletion reduces right inferior prefrontal activation during no-go trials in fast, event-related fMRI. Psychopharmacol 179:791-803.

167. Castellanos FX, Elia J, Kruesi MJP, Gulotta CS, Mefford IN, Potter WZ, Ritchie GF, Rapoport JL. 1994. Cerebrospinal fluid monoamine metabolites in boys with attention-deficit hyperactivity disorder. Psychiat Res 52:305-316.

168. Hegerl U. 1998. Event-related potentials and clinical response to serotonin agonists in patients with affective disorders. Eur Arch Psychiat clin Neurosci 248 (Suppl. 2):S75.

169. Nathan PD, O'Neill B, Croft RJ. 2005. Is the Loudness Dependence of the Auditory Evoked Potential a Sensitive and Selective In Vivo Marker of Central Serotonergic Function? Neuropsychopharmacol 30:15841585.

170. Gallinat J, Stroehle A, Lang UE, Bajbouj M, Kalus P, Montag C, Seifert F, Wernicke C, Rommelspacher $\mathrm{H}$, Rinneberg $\mathrm{H}$, Schubert $\mathrm{F}$. 2005. Association of human hippocampal neurochemistry, serotonin transporter genetic variation, and anxiety. Neuroimage 26:123-131.

171. Carrilo-de-la-Pena MT. 2001. One year test-retest reliability of auditory evoked potentials (AEEPs) to tones of increasing intensity. Psychophysiol 38:417-424.

172. Dykman RA, Holcomb PJ, Ackerman PT, McCray DS. 1983. Auditory ERP augmentation-reduction and methyl- phenidate dosage needs in attention and reading disordered children. Psychiat Res 9:255-269.

173. Bruneau N, Barthelemy C, Roux S, Jouve J, Lelord G. 1989. Auditory evoked potential modifications according to clinical and biochemical responsiveness to fenfluramine treatment in children with autistic behavior. Neuropsychobiol 21:4852.

174. Jemel B, Achenbach C, Müller B, Röpcke B, Oades RD. 2002. Mismatch negativity results from bilateral asymmetric dipole sources in the frontal and temporal lobes. Brain Topogr 15:13-27.

175. Fallgatter AJ, Herrmann MJ, Roemmler $\mathrm{J}$, Ehlis A-C, Wagener A, Heidrich A, Ortega $G$, Zeng $Y$, Lesch KP. 2005. Allelic variation of serotonin transporter function modulates the brain electrical response for error processing. Neuropsychopharmacol 29: 1506-1511.

176. Curran S, Purcell S, Craig I, Asherson P, Sham P. 2005. The Serotonin Transporter Gene as a QTL for ADHD. Am J Med Genet 134B:42-47.

177. Lakatos K, Nemoda Z, Birkas E, Ronai Z, Kovacs E, Ney K, Toth I, Sasvari-Szekely M, Gervai J. 2003. Association of D4 dopamine receptor gene and serotonin transporter promoter polymorphisms with infants' response to novelty. Mol Psychiat 8:90-97.

178. Seeger G, Schloss P, Schmidt MH. 2001. Marker gene polymorphisms in hyperkinetic disorder - predictors of clinical response to treatment with methylphenidate? Neurosci Lett 313:45-48.

179. Uzbekov MG. 2006. Hyperkinetic syndrome as a manifestation of a disturbance of metabolism and mental development. In: Oades RD, editor. Progress in Attention-Deficit/Hyperactivity Disorder 
Research. Hauppauge, New York: Nova Science Publishers, Inc. p. In Press.

180. David SP, Murthy NV, Rabiner EA, Munafo MR, Johnstone EC, Jacob R, Walton RT, Grasby PM. 2005. A Functional Genetic Variation of the Serotonin (5-HT) Transporter Affects 5- $\mathrm{HT}_{1 \mathrm{~A}}$ Receptor Binding in Humans. J Neurosci 25:2586-2590.

181. Bantick RA, de Vries MH, Grasby PM. 2005. The effect of a $5-\mathrm{HT}_{1 \mathrm{~A}}$ receptor agonist on striatal dopamine release. Synapse 57:67-75.

182. Martin-Ruiz R, Puig MV, Celada P, Shapiro DA, Roth BL, Mengod G, Artigas F. 2001. Control of serotonergic function in medial prefrontal cortex by serotonin-2A receptors through a glutamate-dependent mechanism. J Neurosci 21:9856-9866.

183. Ferre S, Artigas F. 1993. Dopamine D2 receptor-mediated regulation of serotonin extracellular concentration in the dorsal raphe nucleus of freely moving rats. J Neurochem 61:772-775.

184. Reneman L, De Bruin K, Lavalaye J, Guning WB, Booij J. 2001. Addition of a 5-HT receptor agonist to methylphenidate potentiates the reduction of $\left[{ }^{123} \mathrm{I}\right] \mathrm{FP}-\mathrm{CIT}$ binding to dopamine transporter in rat frontal cortex and hippocampus. Synapse 39:193-200.

185. Fleckenstein AE, Hanson GR. 2003. Impact of psychostimulants on vesicular monoamine transporter function. Eur J Pharmacol 479:283-289.

186. Truong JG, Newman AH, Hanson GR, Fleckenstein AE. 2004. Dopamine D2 receptor activation increases vesicular dopamine uptake and redistributes vesicular monoamine transporter-2 protein. Eur J Pharmacol 504:27-32.

187. Oades RD, Sadile AG, Sagvolden T, Viggiano D, Zuddas A, Devoto P, Aase H,
Johansen EB, Ruocco LA, Russell VA. 2005. The control of responsiveness in ADHD by catecholamines: evidence for dopaminergic, noradrenergic, and interactive roles. Dev Sci 8:122-131.

188. Sonuga-Barke EJS, Williams E, Hall M, Saxton T. 1996. Hyperactivity and delay aversion. III: The effect on cognitive style of imposing delay after errors. J Child Psychol Psychiat 37:189-194.

189. Neef NA, Bicard DF, Endo S. 2001. Assessment of impulsivity and the development of self-control in students with attention deficit hyperactivity disorder. J Appl Behav Anal 34:397-408.

190. Kuntsi J, Oosterlaan J, Stevenson J. 2001. Psychological mechanisms in hyperactivity; I Response inhibition deficit, working memory impairment, delay aversion, or something else? J Child Psychol Psychiat 42:199-210.

191. Tripp G, Alsop B. 2001. Sensitivity to reward delay in children with attention deficit hyperactivity disorder (ADHD). J Child Psychol Psychiat 42:691-698.

192. Winstanley CA, Theobald DEH, Cardinal RN, Robbins TW. 2004. Contrasting Roles of Basolateral Amygdala and Orbitofrontal Cortex in Impulsive Choice. J Neurosci 24:4718-4722.

193. Solanto MV, Abikoff H, Sonuga-Barke EJS, Schachar RJ, Logan GD, Wigal T, Hechtman L, Hinshaw S, Turkel E. 2001. The ecological validity of delay aversion and response inhibition as measures of impulsivity in AD/HD: a supplement to the NIMH multimodal treatment study of AD/HD. J Abnorm Child Psychol 29:215-228.

194. Schultz W. 2002. Getting formal with dopamine and reward. Neuron 36:241-263.

195. Oades RD. 1999. Dopamine: Go/No-Go motivation vs. switching. Commentary on 
Depue \& Collins "Neurobiology of the Structure of Personality: Dopamine, Facilitation of Incentive Motivation and Extraversion". Behav Brain Sci 22:532-533.

196. Harris GC, Wimmer M, Aston-Jones GS. 2005. A role for lateral hypothalamic orexin neurons in reward seeking. Nature 437:556559.

197. Federici M, Geracitano R, Bernardi G, Mercuri NB. 2005. Actions of methylphenidate on dopaminergic neurons of the ventral midbrain. Biol Psychiat 57:361-365.

198. Grace AA. 2001. Psychostimulant actions on dopamine and limbic system function: relevance to the pathophysiology and treatment of ADHD. In: Solanto MV, Arnsten AFT, Castellanos FX, editors. Stimulant drugs and ADHD: basic and clinical neuroscience. Oxford: Oxford University Press. p. 134-157.

199. Krause K-H, Dresel SH, Krause J, Kung HF, Tatsch K. 2000. Increased striatal dopamine transporter in adult patients with attention deficit hyperactivity disorder: effects of methylphenidate as measured by single photon emission computed tomography. Neurosci Lett 285:107-110.

200. Volkow ND, Wang G-J, Fowler JS, Logan J, Gerasimov M, Maynard L, Ding Y-S, Gatley SJ, Gifford A, Franceschi D. 2001. Therapeutic doses of oral methylphenidate significantly increase extracellular dopamine in the human brain. J Neurosci 21:RC121 (1$5)$.

201. Gerasimov MR, Franceschi M, Volkow ND, Gifford A, Gatley SJ, Marsteller D, Molina PE, Dewey SL. 2000. Comparison between intra-peritoneal and oral methylphenidate administration: a microdialysis and locomotor study. J Pharmacol Exp Ther 295:51-57.
202. Volkow ND, Wang G-J, Fowler JS, Ding Y-S. 2005. Imaging the Effects of Methylphenidate on Brain Dopamine: New Model on Its Therapeutic Actions for Attention-Deficit/Hyperactivity Disorder. Biol Psychiat 57:1410-1415.

203. Winsberg BG, Comings DE. 1999. Association of the dopamine transporter gene (DAT1) with poor methylphenidate response. J Am Acad Child Adolesc Psychiat 38:1474-1477.

204. Roman T, Szobot C, Martins S, Biederman J, Rohde LA, Hutz MH. 2002. Dopamine transporter gene and response to methylphenidate in attention-deficit/ hyperactivity disorder. Pharmacogenet 12 : 497-499.

205. Rohde LA, Roman T, Szobot C, Cunha RD, Hutz MH, Biederman J. 2003. Dopamine transporter gene, response to methylphenidate and cerebral blood flow in attention-deficit/hyperactivity disorder: a pilot study. Synapse 48:87-89.

206. Loo SK, Specter E, Smolen A, Hopfer C, Teale PD, Reite ML. 2003. Functional effects of the DAT1 polymorphism on EEG measures in ADHD. J Am Acad Child Adolesc Psychiat 42:986-993.

207. Cheon K-A, Ryu Y-H, Kim J-W, Cho D-Y. 2004. The homozygosity for 10 -repeat allele at dopamine transporter gene and dopamine transporter density in Korean children with attention deficit hyperactivity disorder: relating to treatment response to methylphenidate. Eur Neuropsychopharmacol 15:95-101.

208. Bellgrove MA, Hawi Z, Kirley A, Fitzgerald M, Gill M, Robertson IH. 2005. Association between Dopamine Transporter (DAT1) Genotype, Left-Sided Inattention, and an Enhanced Response to Methylphenidate in Attention-Deficit Hyper-activity 
Disorder Neuropsychopharmacol doi: 10.1038/sj.npp.1300839:1-8.

209. Wienbruch C, Paul I, Bauer S, Kivelitz H. 2005. The influence of methylphenidate on the power spectrum of ADHD children - an MEG study. BMC Psychiatry 5:29.

210. Cornish KM, Manly T, Savage R, Swanson J, Morisano D, Butler N, Grant C, Cross G, Bentley L, Hollis CP. 2005. Association of the dopamine transporter (DAT1) 10/10-repeat genotype with ADHD symptoms and response inhibition in a general population sample. Mol Psychiat doi:10.1038/sj.mp.4001641:1-13.

211. Simseka M, Al-Sharbatib M, Al-Adawib S, Ganguly SS, Lawatia K. 2005. Association of the risk allele of dopamine transporter gene (DAT1*10) in Omani male children with attention-deficit hyperactivity disorder. Clin Biochem in press.

212. Galvan A, Hare TA, Davidson M, Spicer J, Glover G, Casey BJ. 2005. The Role of Ventral Fronto-striatal Circuitry in RewardBased Learning in Humans. I Neurosci 25:8650-8656.

213. Sagvolden $T$, Metzger MA, Schiorbeck HK, Rugland A-L, Spinnangr I, Sagvolden G. 1992. The spontaneously hypertensive rat (SHR) as an animal model of childhood hyperactivity (ADHD): changed reactivity to reinforcers and to psychomotor stimulants. Behav Neur Biol 58:103-112.

214. Pietras CJ, Cherek DR, Lan SD, Tcheremissine OV, Steinberg JL. 2004. Effects of methylphenidate on impulsive choice in adult humans. Psychopharmacol 170:390-398.

215. Volkow ND, Wang GJ, Fowler JS, Logan J, Jayne M, Franceschi D, Wong C, Gatley SJ, Gifford AN, Ding YS, Pappas N. 2002. "Nonhedonic" food motivation in humans involves dopamine in the dorsal striatum and methylphenidate amplifies this effect. Synapse 44:175-180.

216. Bolanos CA, Barrot $M$, Berton O, Wallace-Black D, Nestler EJ. 2003. Methylphenidate treatment during pre- and peri-adolescence alters behavioral responses to emotional stimuli at adulthood. Biol Psychiat 54:1317-1329.

217. Mateo $Y$, Budygin EA, John CE, Jones SR. 2004. Role of serotonin in cocaine effects in mice with reduced dopamine transporter function. Proc Natl Acad Sci (USA) 101:372-377.

218. Budygin EA, Brodie MS, Sotnikova TD, Mateo Y, John CE, Cyr M, Gainetdinov RR, Jones SR. 2004. Dissociation of rewarding and dopamine transporter-mediated properties of amphetamine. Proc Natl Acad Sci (USA) 101:7781-7786.

219. Ahn K-C, Pazderka-Robinson $H$, Clements R, Ashcroft R, Ali T, Morse C, Greenshaw AJ. 2005. Differential effects of intra-midbrain raphé and systemic $8-\mathrm{OH}-$ DPAT on VTA self-stimulation thresholds in rats. Psychopharmacol 178:381-388.

220. Dekeyne A, Gobert A, Auclair A, Girardon S, Millan MJ. 2002. Differential modulation of efficiency in a food-rewarded "differential reinforcement of low-rate" 72-s schedule in rats by norepinephrine and serotonin reuptake inhibitors. Psychopharmacol 162:156-167.

221. Lucki I. 1998. The spectrum of behaviors influenced by serotonin. Biol Psychiat 44:151-162.

222. Cherek DR, Lane SD, Pietras CJ, Steinberg JL. 2002. Effects of chronic paroxetine administration on measures of aggressive and impulsive responses of adult males with a history of conduct disorder. Psychopharmacol 159:266-274. 
223. Sargent PA, Williamson DJ, Pearson G, Odontiadis J, Cowan PJ. 1997. Effect of paroxetine and nefazodone on 5-HT1A receptor sensitivity. Psychopharmacol 132:296-302.

224. Balleine $B$, Fletcher $N$, Dickinson $A$. 1996. Effect of the $5 \mathrm{HT}_{1 \mathrm{~A}}$ agonist, $8-\mathrm{OH}-$ DPAT, on instrumental performance in rats. Psychopharmacol 125:79-88.

225. Fletcher PJ. 1994. Effects of 8-OHDPAT, 5-CT and muscimol on behaviour maintained by a DRL 20s schedule of reinforcement following microinjection into the dorsal or median raphe nuclei. Behav Pharmacol 5:326-336.

226. Fletcher PJ, Korth KM. 1999. Activation of $5-\mathrm{HT} 1 \mathrm{~B}$ in the nucleus accumbens reduces amphetamine induced enhancement of responding for conditioned reward. Psychopharmacol 142:165-174.

227. Evenden JL. 1999. The pharmacology of impulsive behaviour in rats. VII: the effects of serotonergic agonists and antagonists on responding under a discrimination task using unreliable visual stimuli. Psychopharmacol 146:422-431.

228. Cousins MS, Vosmer G, Overstreet DH, Seiden LS. 1999. Rats selectively bred for responsiveness to 5-hydroxytryptamine ${ }_{1 \mathrm{~A}}$ receptor stimulation: differences in differential reinforcement of low rate 72 second performance and response to serotonergic drugs. J Pharmacol Exp Ther 292:104-113.

229. Thiebot M-H, Martin P, Puech AJ. 1992. Animal behavioural studies in the evaluation of antidepressant drugs. $\mathrm{Br} J$ Psychiat suppl.:44-50.

230. Bizot J-C, Le Bihan C, Puech AJ, Hamon $M$, Thiebot $M-H$. 1999. Serotonin and tolerance to delay of reward in rats. Psychopharmacol 146:400-412.
231. Denk F, Walton $M E$, Jennings $K A$, Sharp T, Rushworth MFS, Bannerman DM. 2005. Differential involvement of serotonin and dopamine systems in cost-benefit decisions about delay or effort. Psychopharmacol 179:587-596.

232. Pliszka SR, Maas JW, Javors MA, Rogeness GA, Baker J. 1994. Urinary catecholamines in attention-deficit hyperactivity disorder with and without comorbid anxiety. J Am Acad Child Adolesc Psychiat 33:1165-1173.

233. Raskin LA, Shaywitz SE, Shaywitz BA, Anderson GM, Cohen DJ. 1984. Neurochemical correlates of attention deficit disorder. Pediatr Clin N Am 31:387396.

234. Hunt RD, Cohen DJ, Anderson G, Clark L. 1984. Possible change in noradrenergic receptor sensitivity following methylphenidate treatment: growth hormone and MHPG response to clonidine challenge in children with attention deficit disorder and hyperactivity. Life Sci 35:885-897.

235. Shekim WO, Javaid J, Dekirmenjian H, Chapel JL, Davis JM. 1982. Effects of damphetamine on urinary metabolites of dopamine and norepinephrine in hyperactive boys. Am J Psychiat 139:485488.

236. Shekim WO, Javaid J, Davis JM, Bylund DB. 1983. Urinary MHPG and HVA excretion in boys with attention deficit disorder and hyperactivity treated with d-amphetamine. Biol Psychiat 18:707-713.

237. Shen YC, Wang YF. 1984. Urinary 3methoxy-4-hydroxyphenylglycol sulfate excretion in seventy three schoolchildren with minimal brain dysfunction. Biol Psychiat 19:861-869.

238. Zametkin AJ, Karoum F, Linnoila $M$, Rapoport JL, Brown GL, Chuang LW, Wyatt 
RJ. 1985. Stimulants, urinary catecholamines and indoleamines in hyperactivity: a comparison of methylphenidate and dextroamphetamine. Arch Gen Psychiat 42:251-255.

239. Jacobowitz D, Sroufe LA, Stewart $M$, Leffert N. 1990. Treatment of attentional and hyperactivity problems in children with sympathomimetic drugs: a comprehensive review. J Am Acad Child Adolesc Psychiat 29:677-688.

240. Castellanos FX. 1999. The psychobiology of attention-deficit/ hyper-activity disorder. In: Quay HC, Hogan TP, editors. Handbook of disruptive behavior disorders. New York: Kluwer Academic/ Plenum Publishers. p. 179-198.

241. Halperin JM, Newcorn JH, Koda VH, Pick L, McKay KE, Knott P. 1997. Noradrenergic mechanisms in ADHD children with and without reading disabilities: a replication and extension. J Am Acad Child Adolesc Psychiat 36:16881697.

242. Kusaga A, Yamashita Y, Koeda T, Hiratani M, Kaneko M, Yamada S, Matsuishi T. 2002. Increased urine phenylethylamine after methylphenidate treatment in children with ADHD. Ann Neurol 52:371-374.

243. Potter WZ, Hsiao JK, Goldman SM. 1989. Effects of renal clearance on plasma concentrations of homovanillic acid. Arch Gen Psychiat 46:558-562.

244. Shetty T, Chase TN. 1976. Central monoamines and hyperkinesis of childhood. Neurol 26:1000-1002.
245. Irwin M, Belendiuk K, McCloskey K, Freedman DX. 1981. Tryptophan metabolism in children with attentional deficit disorder. Am J Psychiat 138:10821085.

246. Spivak B, Vered Y, Yoran-Hegesh R, Graff $E$, Averbuch $E$, Vinokurow $S$, Weizman A, Mester R. 2001. The influence of three months of methylphenidate treatment on platelet-poor plasma biogenic amine levels in boys with attention deficit hyperactivity disorder. Hum Psychopharmacol Clin Exp 16:333-337.

247. Laufer MW, Denhoff E, Solomons G. 1957. Hyperkinetic impulse disorder in children's behaviour problems. Psychosom Med 19:38-49.

248. Ashtari M, Kumra S, Bhaskar SL, Clarke $T$, Thaden $E$, Cervellione $K L$, Rhinewine J, Kane JM, Adesman A, Milanaik R, Maytal J, Diamond A, Szeszko P, Ardekani BA. 2005. Attention-deficit/hyperactivity disorder: $A$ preliminary diffusion tensor imaging study. Biol Psychiat 57:448-455.

249. Satterfield JH, Schell AM, Nicholas T. 1994. Preferential processing of attended stimuli in attention-deficit hyperactivity disorder and normal boys. Psychophysiol 31:1-10.

250. Johnstone SJ. 1999. Auditory eventrelated potentials in attention-deficit hyperactivity disorder: developmental and clinical aspects. University of Wollongong: $\mathrm{PhD}$ Thesis. 